\title{
DA IMPORTÂNCIA ESTRATÉGICA NA ECONOMIA COLONIAL AOS PROCESSOS DE FRAGMENTAÇÃO TERRITORIAL NO NORDESTE PARAENSE: DINÂMICAS TERRITORIAIS E REPRODUÇÃO DO ESPAÇO RURAL NO MUNICÍPIO DE MARACANÃ (PARÁ/BRASIL)
}

\author{
FROM THE STRATEGIC IMPORTANCE IN THE COLONIAL ECONOMY TO THE TERRITORIAL \\ FRAGMENTATION PROCESSES IN THE NORTHEAST OF THE STATE OF PARÁ: TERRITORIAL DYNAMICS AND \\ REPRODUCTION OF RURAL AREA IN THE CITY OF MARACANÃ (PARÁ/BRAZIL)
}

\author{
Carlos Jorge Nogueira da Castro ${ }^{1,2}$, Daniel Sombra ${ }^{1,2}$, João Barros Filho², Nonato Sousa ${ }^{2}$ \\ ${ }^{1}$ Universidade Federal do Pará (UFPA), Belém, PA, Brasil \\ 2 Universidade do Estado do Pará (UEPA), Belém, PA, Brasil
}

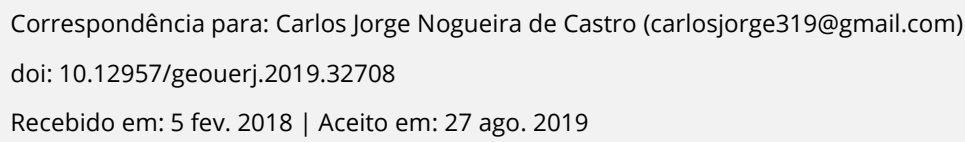

\section{RESUMO}

A compreensão do processo de colonização e formação territorial do Nordeste Paraense, torna-se de suma importância para a interpretação de fenômenos espaciais que se perpetuam nesse contexto espacial. Desta forma deve-se enfatizar a valor estratégico que o território da extinta comarca de Cintra, atualmente município de Maracanã teve no processo de colonização da Zona Bragantina. Assim o presente artigo tem como objetivo apresentar as principais dinâmicas territoriais responsáveis pelo processo de formação territorial de Maracanã, levando principalmente em consideração o sistema de transportes como meio estruturador das relações espaciais. Para anteder tal objetivo recorremos à pesquisa qualitativa que auxiliou no levantamento bibliográfico, na coleta de dados estatísticos de instituições públicas, e também na realização de trabalhos de campo nos períodos de 2016 e 2017, que aliados a cartografia e o geoprocessamento de imagens permitiram a confecções de representações cartográficas essências para a realização da análise e discussão do tema. Por fim chegou-se à conclusão de que para compreender os processos de fragmentação e estruturação espacial do Nordeste Paraense, em especial a zona bragantina, devemos considerar as intencionalidades dos agentes hegemônicos locais que realizam constantes modificações socioespaciais de acordo com seus interesses.

Palavras-chave: colonização; formação territorial; fragmentação territorial; espaço rural; Maracanã.

\begin{abstract}
Understanding the process of Northeast Parás colonization and territorial formation becomes very important for interpretation of spatial phenomena that perpetuate themselves in this spatial context. Thereby, it is necessary to emphasize the strategic value that the territory of former district of Cintra (nowadays municipality of Maracanã) had in Bragantine Zone's colonization process. Thus, this paper aims to show the main territorial dynamics responsible for the Maracanã's territorial formation process, taking especially into account the transport system as a structuring means of spatial relations. Fort that, we used qualitative research that helped us about bibliographic survey, collecting public institutions data, as well as in the field works made in 2016 and 2017. This data allied to cartography tools and geoprocessing of images allowed the confections of cartographic representations, essential to analysis of this subject. Last, we concluded that in order to understand Northeast Parás spatial structuring and fragmentation process, especially in Bragantine Zone, we must consider local hegemonic agents intentionalities, who make constant socio-spatial changes according to their interests.
\end{abstract}

Keywords: colonization; territorial formation; territorial fragmentation; rural space; Maracanã.

\section{APRESENTAÇÃO}


A partir da Capital do estado do Pará, Belém, seguindo a uma distância de 138 km (segmento retilíneo) em sentido nordeste, na angulação de $57^{\circ}$, encontra-se a cidade de Maracanã, embora a distância rodoviária seja algo equivalente a $164 \mathrm{~km}$. O município de Maracanã está localizado na mesorregião geográfica do Nordeste Paraense (mapa 1), e na microrregião do Salgado ${ }^{1}$, com sua sede municipal estando pontuada a $0^{\circ} 46^{\prime} 03^{\prime \prime}$ de latitude sul e $47^{\circ} 27^{\prime} 12^{\prime \prime}$ de longitude oeste. É banhada ao norte pelo Oceano Atlântico, possuindo limites administrativos a leste com os municípios de Salinópolis, Santarém Novo e São João de Pirabas; ao sul com o município de Igarapé-Açu; e a oeste com os municípios de Marapanim e Magalhães Barata.

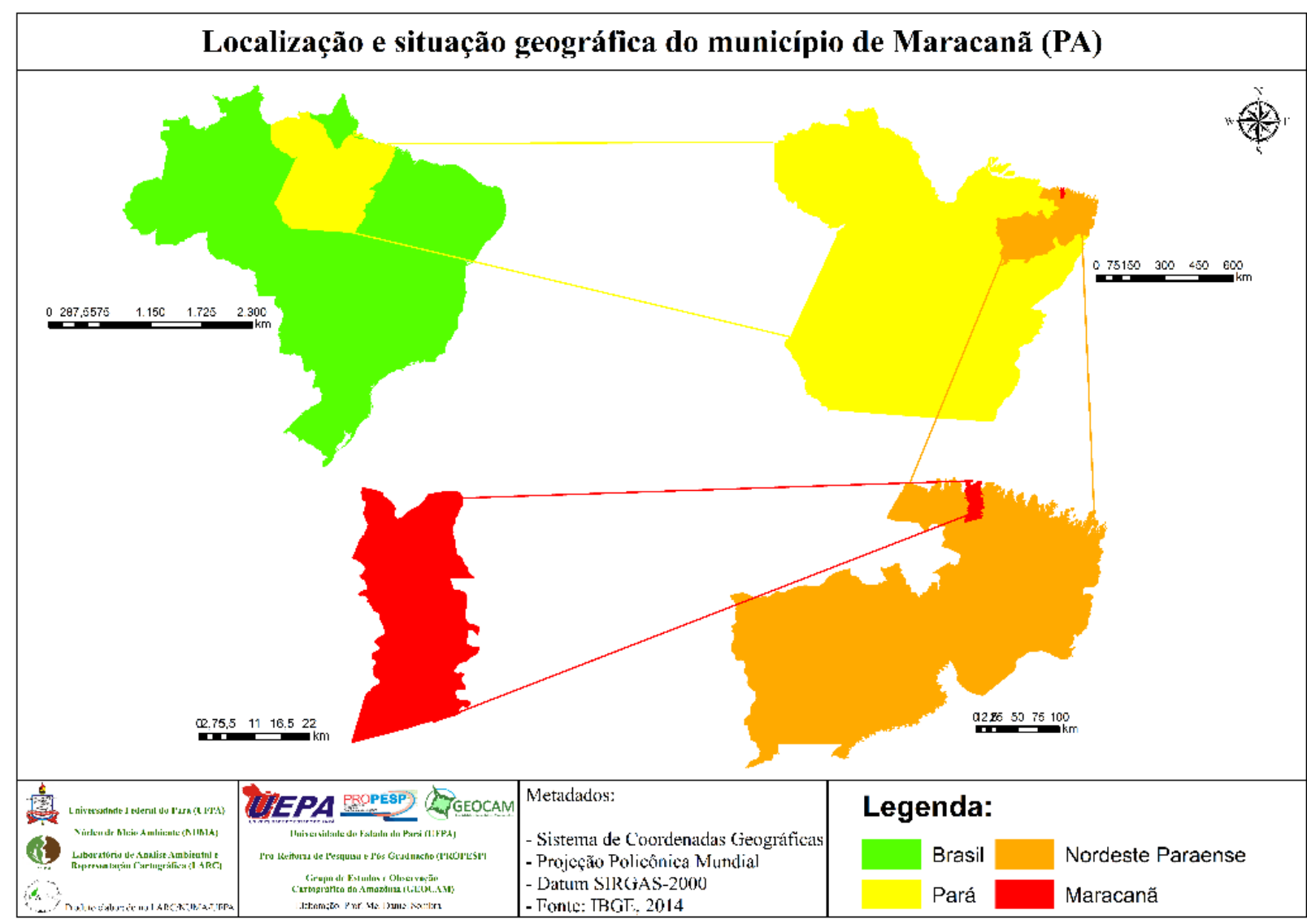

\footnotetext{
${ }^{1}$ A regionalização em questão diz respeito à classificação regional de 1990 do IBGE, a qual será utilizada nesse artigo por expressar bem o conjunto espacial de referência para a compreensão da formação rural da hinterlândia de Belém, que corresponde, grosso modo, ao Nordeste Paraense. A microrregião do Salgado, por sua vez, é composta pelos municípios de Colares, Curuçá, Magalhães Barata, Maracanã, Marapanim, Salinópolis, São Caetano de Odivelas, São João da Ponta, São João de Pirabas, Terra Alta e Vigia de Nazaré. Por outro lado, é necessário ter em mente que o IBGE estabeleceu uma nova regionalização em 2017, substituindo as mesorregiões por regiões intermediárias, e as microrregiões por regiões imediatas. Conforme esta regionalização, que não é utilizada neste artigo, Maracanã se encontra na região intermediária de Castanhal, bem como na região imediata de Castanhal.
} 
Mapa 1. Localização e situação geográfica do município de Maracanã (PA). Fonte: GEOCAM (2017), com base em informações do IBGE (2014).

Sua sede municipal, a cidade de Maracanã, encontra-se às margens da Baía do Maracanã, formada a partir do encontro do rio Maracanã com o rio Caripi. O exercício de reconhecimento cartográfico, como o apresentado nas linhas acima, é importante no processo de análise histórico-geográfica da cidade de Maracanã. Segundo dados oficiais disponibilizados pelo Instituto Brasileiro de Geografia e Estatística (IBGE), admite-se que houve em 1653 a formação do atual núcleo urbano da cidade de Maracanã, neste momento ocupado por uma aldeia de ameríndios da etnia Maracanã. Entretanto, há relatos de historiadores que abordam que entre 1613 e 1614 colonizadores franceses estiveram na aldeia dos Maracanãs, bem como os espanhóis estiveram em 1622 às proximidades da mesma. Entretanto, sobre a formação do atual núcleo urbano de Maracanã ainda há pouca literatura. Os antecedentes históricosgeográficos ainda estão em curso de descobertas.

A presença dos franceses na Amazônia é abordada por Carvalho (2014) quando apresenta que após o contato com colonizadores estrangeiros foi criado o costume tribal de acompanhar as caravanas por caminhos fluviais e terrestres. Para o autor, há relatos de que uma esquadra francesa que partiu de São Luís do Maranhão em junho de 1613, com grande contingente de soldados e chefes indígenas da nação Tubinambá com o propósito de explorar o vale do rio Tocantins ${ }^{2}$. Segundo relatos de históriadores da época, antes de penetrar no rio Tocantis a expedição já contava com milhares de índios. Assim, Carvalho (2014, p. 39) descreve o trajeto marítimo:

\footnotetext{
O trajeto marítimo entre a ilha do Maranhão (Upaon-açu dos indígenas) e a entrada do rio Tocantins na baía de Guajará (Belém) implicava necessariamente a passagem pela aldeia de Caeté, povoada pelos tubinambás, e pela aldeia de Maracanã, também habitada pelos tupinambás. Nessas duas grandes povoações de índios do Pará, os franceses recrutaram os remadores de suas canoas para subirem o Tocantins e o Araguaia.
}

O fragmento acima apresenta uma cooperação de agentes no empreendimento colonial e mercantil na região, que possibilitou a entrada da coroa francesa a partir de 1612. No entanto, a Coroa Portuguesa desenvolveu um plano astucioso para a efetivação de seu empreendimento político e econômico no

\footnotetext{
${ }^{2} \mathrm{O}$ vale do Tocantins localiza-se no estado do Pará, em uma região hidrográfica que divide o continente do Nordeste Paraense com a Ilha de Marajó. Com a contribuição de grandes tributários, como os rios Guamá, Moju e Acará à direita, e o rio Pará à esquerda, o vale do Tocantins forma a Baía do Marajó.
} 
processo de expansão do seu domínio territorial, ainda no contexto da União Ibérica (ANDRADE, 1993). O que se deu a partir da conexão entre as capitanias do Maranhão e do Grão-Pará, com a formação das cidades de São Luís e Belém, e o uso de estratégias de instalações religiosas e de fortificações militares às margens dos rios na costa da Amazônia Oriental (MACHADO, 1997).

A fundação da cidade de Belém concentra maior esforço dos pesquisadores que se debruçam sobre o processo de formação territorial do Nordeste Paraense, porém, ainda se verifica uma pequena literatura, no campo da Geografia, que aborde a formação das cidades históricas e estratégicas do ponto de vista geográfico como a cidade de Maracanã. Assim, adotou-se nesta pesquisa o viés qualitativo que pode ser verificado nas sessões seguintes que tratam dos processos de colonização e ocupação do Nordeste Paraense. Também serão analisados os processos de reprodução do modo de vida rural e urbano de Maracanã, frente aos processos de fragmentação de seu território, promovidos pela mudança no padrão de ocupação amazônica.

Para Costa (1991, p. 13), o conceito de políticas territoriais abrange "toda e qualquer atividade estatal que implique, simultaneamente, uma dada concepção do espaço nacional, uma estratégia de intervenção ao nível da estrutura territorial, e por fim, mecanismos concretos que sejam capazes de viabilizar essas políticas”. Conforme Soares et al (2016, p. 49), neste raciocínio, o Estado possui seu próprio ritmo, adentrando aos ditames da racionalidade econômica e converte o desenvolvimento da técnica e da produção em seus objetivos, mas a sua valorização advém do controle do território. A soberania se torna a chave, sendo o território diferentemente valorizado pelo Estado e por empresas, estando aí a articulação para relacionar políticas territoriais e dinâmicas territoriais.

O objetivo é apresentar as principais dinâmicas territoriais no processo de formação de Maracanã, considerando o sistema de circulação como elemento estruturador das relações espaciais. Castro (2017, p. 278) frisa que para compreender as dinâmicas espaciais do Nordeste Paraense é necessário considerar o papel exercido pela Estrada de Ferro de Bragança (EFB), no trajeto Belém-Bragança, a qual, para o 
autor, promoveu um Padrão de Ocupação Intermediário3, nomeado de "Estrada - Terra Firme - Solo", onde a produção objetivava garantir a reprodução das relações de produção na capital, Belém.

Neste contexto, os trabalhos de Égler (1961), Valverde e Dias (1967), Penteado (1967; 1973), Veríssimo (1970), Cruz (1973), Furtado (1981; 1987), Penner (1984), Loureiro (1985), Gonçalves (2012) e Ribeiro $(2015 ; 2017)$ apresentam grande relevância para a abordagem geográfica desta pesquisa, a partir do estabelecimento de linhas mestras que auxiliam na compreensão dos processos de colonização e ocupação da região, bem como o abastecimento agrícola proveniente dos municípios do Nordeste Paraense para Belém.

Este artigo deriva, por fim, do conjunto de pesquisas desenvolvidas pelo Grupo de Estudos e Observação Cartográfica da Amazônia (GEOCAM), no âmbito da Universidade do Estado do Pará (UEPA), e além do uso de revisão de literatura, faz uso de dados primários obtidos em trabalhos de campo realizados em 2016 e 2017, além de dados secundários de âmbito estatístico de instituições públicas brasileiras. Além deste introdutório, o artigo se estrutura nos antecedentes históricos de Maracanã (Cintra), o processo de colonização e ocupação na porção Nordeste Paraense, o processo de fragmentação territorial, e mais recentemente a reprodução do espaço rural do município de Maracanã (limite atual), para então adentrar na análise dos processos de reprodução no espaço rural do município.

\section{OS PROCESSOS DE COLONIZAÇÃO E OCUPAÇÃO DO NORDESTE PARAENSE}

A compreensão da gênese dos processos de ocupação do Nordeste Paraense auxilia na interpretação de tendências de larga duração neste contexto espacial, possuindo relevância geográfica e histórica. Neste ínterim, cabe destacar a importância fundamental que o território da comarca e posteriormente município

\footnotetext{
${ }^{3}$ Nesse caso, trata-se de um diálogo de Castro (2017) com a obra de Gonçalves (2012), que propôs dois padrões de organização espacial existentes na Amazônia: $a$ ) o padrão Rio - Várzea - Floresta; e, $b$ ) o padrão Estrada - Terra Firme Subsolo. Castro (2017) propõe um padrão Estrada - Terra Firme - Solo para a região bragantina. Já Miranda (2009), analisando os municípios de Castanhal e Igarapé-Açu (na mesma região de Maracanã), propôs outra periodização de padrões espaciais para essa área: a) Padrão Rio - Várzea - Floresta (1616-1874); b) Padrão Cidade - Estrada de Ferro - Colônia (1875 - 1965); c) Padrão Rodovia - Cidade - Colônia (anos 1960 em diante).
} 
de Cintra (atual Maracanã) possuiu no processo de colonização da Zona Bragantina devido à sua localização estratégica.

A cidade de Maracanã foi construída às margens da Baía do Maracanã, possibilitando aos colonizadores, maior fluidez através dos rios para a conquista fluvial, a qual foi ponteada por pequenas incursões terrestres (CRUZ, 1973). Por outro lado, os rios forneceram o alimento de base para os primeiros assentamentos coloniais: o pescado (SOARES, 2016). Conforme Veríssimo (1970, p. 90), a alimentação encontrada nos caminhos percorridos pelas expedições realizadas entre 1638 e 1639 era fácil e abundante. Tal fertilidade, bem como a tecnologia empregada pelos habitantes locais ${ }^{4}$ com quem os colonizadores entravam em contato deram as bases materiais para o estabelecimento da colonização da Amazônia (FURTADO, 1981). Conforme Soares (2016, p. 59):

\footnotetext{
Observando as técnicas agrícolas e pesqueiras das várias comunidades ameríndias, os lusitanos garantiram a alimentação dos núcleos coloniais instalados no vale amazônico Os itens mais pescados nessa primeira etapa da colonização eram o pirarucu (Arapaima gigas), o peixe-boi amazônico (Trichechus inunguis), espécies regionais de tartarugas e peixes típicos de água doce. Neste período, os nativos foram tratados como força de trabalho a serviço da Coroa, não podendo ser escravizados por colonos individuais sem autorização expressa em carta régia.
}

A partir do diálogo com a obra de Machado (1997), que analisa o controle territorial na formação amazônica, Soares (2016) afirma que há particularidades que converteram a colonização da Amazônia, desde os seus albores, em uma formação espacial diferenciada do Estado do Brasil, pois, na formação espacial brasileira "a autonomia dos senhores de terra era praticamente total" (COSTA, 1991, p.28), enquanto que na formação espacial amazônica, os ameríndios, sob o comando dos jesuítas, então fiéis depositários da Coroa, organizavam as chamadas campanhas de pesca para abastecer as cidades criadas (FURTADO, 1981).

\footnotetext{
${ }^{4}$ Gualberto (2009, p. 58) enfatiza que "para estabelecer o controle desse extremo norte, muitas foram as batalhas travadas contra os ingleses, holandeses e franceses. Em todas as batalhas, foram utilizadas as embarcações que transportavam militares, religiosos e índios catequizados. Conhecedores da geografia local, os índios foram muito importantes para conduzirem em suas embarcações e/ou embarcações lusitanas, os missionários e militares portugueses para o confronto com os estrangeiros. [...]. As disputas garantiram à coroa portuguesa o controle dos rios, furos e igarapés que compõem a desembocadura do Amazonas, da ilha do Marajó, completando-se com o Tocantins, já controlados logo após a expulsão dos franceses de São Luís do Maranhão. O controle desses rios que contornam o Marajó gerou novas funções aos mesmos. Esses foram transformados em vias marítimas para o trânsito de embarcações lusitanas que ligassem o Cabo Norte (Amapá) à cidade do Pará (Belém), concomitantemente a São Luís do Maranhão, fechando assim o cerco contra as pretensões estrangeiras".
} 
Para Gonçalves (2012), a partir das dinâmicas inseridas nesse período surgiram pequenos núcleos formados pela ação de companhias religiosas e de colonizadores, que mais tarde, tornaram-se cidades capitaneadas pelo primeiro padrão de ocupação da Amazônia que possuía o rio como meio de circulação. Ressalta-se que esses primeiros núcleos se situavam basicamente no litoral paraense. Por outro lado, adentrando o continente, o rio Guamá se destacava por interligar parte do trecho de Belém às cidades de Bragança e São Luís. A partir das primeiras incursões no litoral paraense é possível compreender a estruturação das cidades, fortemente vinculadas ao meio de circulação marítimo.

Destarte, no século XVII, o primeiro sistema de controle territorial foi estrategicamente pensado e executado, com a instalação de fortins nos núcleos urbanos, visualizando uma segurança, do ponto de vista militar, contra outras nações e contra-ataques de grupos indígenas presentes no entorno (MACHAD0, 1997). Desta forma, o papel desenvolvido pelas ordens religiosas foi fundamental para efetivar a ocupação na porção litorânea, promovendo o que Gonçalves (2012, p. 79) define como o primeiro padrão de ocupação da Amazônia (Rio - Várzea - Floresta) pensado estrategicamente no tripé: circulação, localização e recurso.

Partindo do suposto da circulação como um dos elementos estruturadores da organização espacial, fazse importante considerar a periodização proposta por Ribeiro (2015), para quem o Nordeste Paraense possui quatro distintos períodos em sua formação urbana: a) o Período embrionário, remontando ao processo de colonização da região amazônica no século XVII; b) o Período da colonização da Região Bragantina e da Estrada de Ferro de Bragança (EFB), entre o final do século XIX e a década de 1960; c) o Período de expansão das rodovias, dos anos 1960 aos 1990; e, d) o Período da complexificação da rede urbana diante dos vetores de metropolização do espaço, a partir dos anos 1990. Na representação cartográfica (mapa 2) a seguir observam-se os três primeiros períodos propostos por Ribeiro (2015, p. $5911)$. 


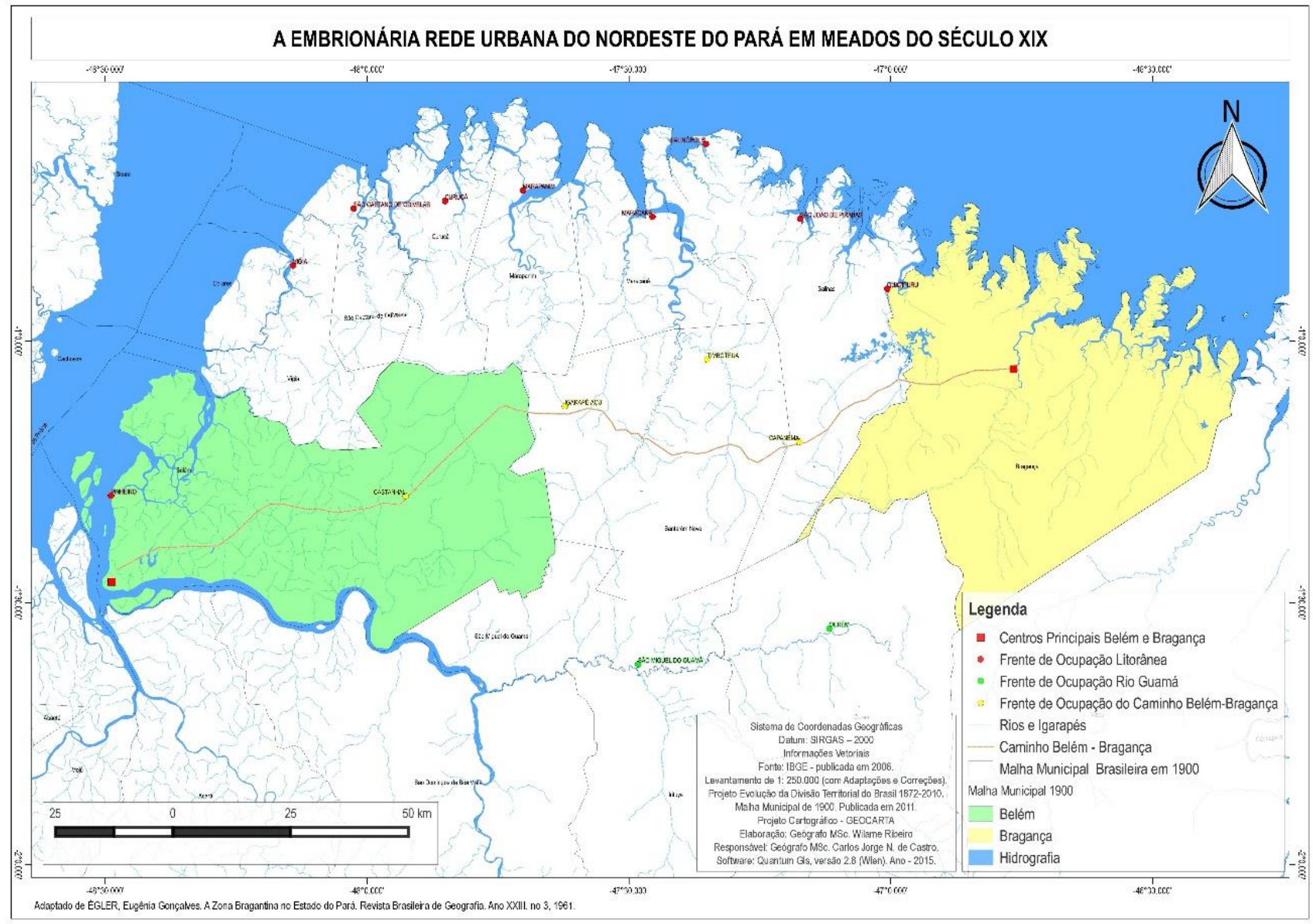

Mapa 2. A Embrionária Rede Urbana do Nordeste Paraense em Meados do Século XIX. Fonte: RIBEIRO (2015, p. 5911), com base nas informações de ÉGLER (1961, p. 532).

No mapa 2 é possível visualizar às três frentes de ocupação que foram caracterizadas que definiram as nucleações na zona costeira paraense. A frente de ocupação guamarina definiu o padrão de colonização das nucleações a partir de Belém à montante do rio Guamá, originando os núcleos de São Miguel do Guamá, São Domingos do Capim e Ourém, na zona de confluência entre a pequena extração de ouro e a produção de cacau, então, a mais importante das drogas do sertão (SOARES, 2016). A cidade de Ourém exercia um papel de mediação, pois, a partir dela se seguia por via terrestre até o trecho navegável do rio Caeté para Bragança.

A partir da terceira fase de ocupação, houve uma projeção da nucleação central de povoamento e atividades produtivas para o trajeto da Estrada de Ferro de Bragança (EFB). Remontando às origens de Maracanã, é necessário atentar ao período que Ribeiro (2015, p. 5910) aponta como embrionário, caracterizado pelo surgimento de núcleos de povoamento urbano, os quais, mais tarde, seriam elevados 
à condição de cidades, todas estabelecidas na linha de costa atlântica ${ }^{5}$, onde se observa a fundação de núcleos urbanos que adiante tornaram-se sedes municipais, providos da malha hidrográfica como meio de circulação.

No primeiro quartel do século XX a ação desempenhada pelos governantes locais em prol da materialização da EFB foi complementada com núcleos agrícolas preferencialmente com mão-de-obra estrangeira (MIRANDA, 2009), mas rapidamente substituída pela mão-de-obra nordestina (ANDRADE, 1970), com o intuito de romper com o agroextrativismo e investir, pela primeira vez, em uma dinâmica "plantacionista" ${ }^{6}$, propiciando uma rica experiência de colonização baseada na agricultura familiar e nos minifúndios (PENTEADO, 1967).

A opção inicial por colonos estrangeiros em detrimento de migrantes das demais regiões brasileiras foi defendida por boa parte das elites locais (SARGES, 2010). Em parte, havia o reconhecimento de que as técnicas agrícolas utilizadas pelos migrantes europeus na Região Sul e na Região Sudeste, sobretudo na economia cafeeira, eram superiores às utilizadas pelos agricultores nacionais (ÉGLER, 1961). Contudo, o pragmatismo venceu, e em poucas décadas, o eixo da Estrada de Ferro era caracterizado por uma cultura de migração nordestina (PENTEADO, 1967; ANDRADE, 1970).

O crescimento das vilas e cidades na Zona Bragantina e sobretudo de Belém exigia alimentos, daí o incremento da agricultura e da pecuária, em simultâneo à pesca. Além das comunidades pré-existentes, o contingente de trabalho se deu com migrantes nordestinos, particularmente os cearenses (MIRANDA, 2009, p. 84). A colonização no Nordeste Paraense deu origem a um lento processo de minifundização, no qual lotes agrícolas passaram a ser cultivados de forma perene com lavouras temporárias,

\footnotetext{
${ }^{5}$ Apesar destas cidades estarem na linha da costa atlântica, estas apresentavam um recuo no continente sendo integradas a partir dos rios. Em 1872, segundo a malha geográfica do IBGE, as sedes dos cinco municípios que compunham a costa litorânea paraense no percurso Belém-São Luís apresentavam aproximadamente as seguintes distâncias: Vizeu (atual Viseu): 25km; Bragança: 30km; Cintra (atual Maracanã): 20Km; Curuçá: 22Km; e Vigia de Nazaré: 8km.

${ }^{6}$ Moreira (2014) afirma que a formação espacial brasileira possuiu como base de seu arranjo espacial uma dinâmica "plantacionista", onde as monoculturas (valor de troca) estabeleceram as motrizes para os arranjos sociais, de modo que a renda diferencial I e a Lei dos Rendimentos Decrescentes descreveram a ocupação das terras do litoral atlântico em direção ao sertão ao montante do Paraná e do São Francisco. Soares (2016) afirma que os mesmos termos não podem ser utilizados para a compreensão da formação espacial amazônica, onde o controle do produto, do processo e da força de trabalho não seguiu a lógica plantacionista, e sim extrativista, o que Moreira (2014) reconhece apenas vagamente ao citar a distinção entre o arranjo espacial jesuíta (hegemônico na formação amazônica) e o arranjo espacial bandeirante (hegemônico na formação brasileira). Neste trabalho, defendemos que a lógica plantacionista foi implantada na Amazônia Oriental durante o ciclo da borracha, como produção subsidiária ao circuito hegemônico, comandado por Belém e Manaus.
} 
principalmente a mandioca, e lavouras permanentes (MIRANDA, 2009, p. 114). A tecnologia do cultivo continua a mesma então disseminada pelo Brasil: a coivara, a qual exigia rotatividade de áreas?

Os minifúndios haviam esgotado os limites do solo para as técnicas utilizadas pelos migrantes (sem complementação da agricultura com o extrativismo dos nativos), incentivando a continuação dos fluxos migratórios rumo às vilas e cidades. Muitas vezes irmãos, primos e filhos deixavam uma base familiar no seu lote e seguiam à cidade (LIMA, 2008, p. 103). Algumas vezes, famílias inteiras continuavam sua rota de migração (LOUREIRO, 1985). Paradoxalmente, o "espaço vazio amazônico" já estava densamente povoado. Além da Região Metropolitana de Belém, as cidades de Vigia, Abaetetuba e Bragança foram as que mais polarizaram esse excedente de trabalho (SOARES, 2016).

Furtado (1987) estudou o município limítrofe, o de Marapanim, nesse período de colonização entre a duração da EFB e a implantação das rodovias, a qual implicou também no estabelecimento de faixas geoeconômicas, onde, conforme a autora, pela primeira vez, a faixa costeira passou a se especializar na pesca e no extrativismo animal e vegetal, ao passo que a faixa imediatamente posterior, vinculada aos pequenos tabuleiros e planaltos costeiros se especializou na agricultura familiar, com destaque para os roçados de mandioca. Valverde e Dias (1967) haviam percebido o início desse processo em todo o vale do Rio Guamá.

\section{A FRAGMENTAÇÃO TERRITORIAL DO MUNICÍPIO DE CINTRA/MARACANÃ}

Em 1900 inicia o processo de fragmentação territorial de Cintra. A primeira secção ocorre para dar origem ao município de Salinópolis. Este processo acompanha um novo padrão regional que começa se impor a partir da consolidação da EFB e de uma malha ferroviária, complementada com uma nascente e ainda incipiente rede rodoviária intermunicipal, em detrimento da então hegemonia das vias fluviais.

\footnotetext{
${ }^{7}$ Essa é a arrumação do espaço quando as políticas de crédito e financiamento da Superintendência do Desenvolvimento da Amazônia (SUDAM) incentivaram a compra de terras na Amazônia. O processo de grilagem e concentração é deveras conhecido para merecer exposição detalhada aqui. A mesorregião do Nordeste Paraense, com a importante exceção dos municípios de Bragança, Moju e Viseu, não conheceu níveis alarmantes de concentração de terras até recentemente (MIRANDA, 2009, p. 110). Entrementes, a tendência nacional do binômio minifúndio-latifúndio (OLIVEIRA, 1997) se afirmou. A migração aumentou implicando na intensificação da produção em pequenos lotes. Sem a possibilidade de maiores pousios, em face à redução dos lotes a um horizonte minúsculo, em poucas gerações apenas o cultivo de mandioca era possível.
} 
Esse processo é bem particular à Zona Bragantina do Nordeste Paraense, ao passo que na macroescala amazônica é a economia da borracha quem traz os afluxos internacionais para as elites regionais, a qual, por sua vez - e ao contrário de alguns autores que fazem uma leitura rasa do período - deu origem à certa complexificação das atividades produtivas agrícolas na hinterlândia de Belém, como atestava o forte movimento regional do sistema portuário de Belém (PENTEADO, 1973).

A economia da borracha também provocou uma ampliação da divisão do trabalho na cidade de Belém, sendo que os proprietários dos negócios urbanos e agrários eram os mesmos, o que levou Sarges (2010) a nomeá-los de "fazendeiros construtores". Outra consequência importante derivada do dinamismo desse ciclo econômico foi justamente o início da mudança de padrão logístico, o qual iria modificar a hinterlândia de Belém, e a Zona Bragantina em particular, nas décadas finais do século XIX e nas décadas iniciais do século XX (PRADO JR., 1977). Esse momento o qual apresentava a economia amazônica era vital para consolidar um projeto de expansão da colonização efetiva do território que, consequentemente, elevasse o patamar da economia paraense fortalecendo a acessibilidade e abastecimento da capital, Belém.

Nesse cenário, as ferrovias e seus ramais desempenharam um papel importante nas economias municipais da época. Para Almeira e Ribeiro (1989), o sistema de transporte ferroviário sempre desempenhou um papel complementar no quadro logístico da Região Norte como um todo, seja em relação ao que nomeiam de "transporte antigo" (hidroviário) ou ao "transporte moderno" (rodoviário e aeroviário). Os autores também defendem periodizar a produção do espaço amazônico a partir do sistema de transportes. Entrementes, conforme Castro (2017), o que é complementar e excepcional na macroescala amazônica torna-se determinante numa análise detida ao Nordeste Paraense, e mais especificamente, à Zona Bragantina.

Em 1872, o município de Maracanã possuía o nome português de Cintra. O antigo nome de Maracanã foi retirado ainda no período pombalino, objetivando o não reconhecimento de nomes indígenas nos municípios, cidades e vilas da região (REIS, 1993). No que tange ao processo de fragmentação territorial do limite originário do município de Cintra, em 1872, este confrontava-se com os limites dos municípios 
de Curuçá, Bethlém (atual Belém), Bragança e Ourém (FAPESPA, 2016). A partir dos dados vetoriais das malhas municipais antigas disponibilizadas pelo IBGE, após análise de geoprocessamento, é possível afirmar que, naquele momento, o município de Cintra possuía a extensão territorial de $3.373,64 \mathrm{~km}^{2}$, a qual foi bastante fragmentada ao longo de um século e meio a partir de processos de desmembramento, remembramento, inclusive com deslocamentos de sedes municipais.

Cabe ressaltar que tais processos acompanham os vetores hegemônicos de circulação em cada período. Conforme é possível visualizar no mapa 3, há uma mudança do topônimo de Cintra novamente para Maracanã em 1900, além de uma perda significativa perda de área, de aproximadamente 67,22\%, ou seja, Cintra (agora Maracanã) perdeu 2.267,76 km² com a emancipação do município de Salinópolis, com sede municipal localizada na costa atlântica.

Na década posterior (anos 1910) ocorreram novos processos de fragmentação na área. O emancipado município de Salinópolis é fragmentado com a criação do município de Quatipuru, com sede municipal localizada à margem do rio Tracuateua, seguindo ainda o padrão de hegemonia da circulação por hidrovias. Ainda em relação às informações visualizadas no mapa 3, observa-se que durante a Era Vargas, em 1933, houve a extinção do município de Salinópolis e o remembramento dessa área ao município de Maracanã. Por outro lado, houve duas mudanças no município limítrofe de Quatipuru. 0 seu topônimo, alterado para Siqueira Campos (homenageando um grande coronel regional), e também mudança de localização da sede administrativa do município, transferida da margem do rio Tracuteua para a margem da Estrada de Ferro de Bragança (EFB). 


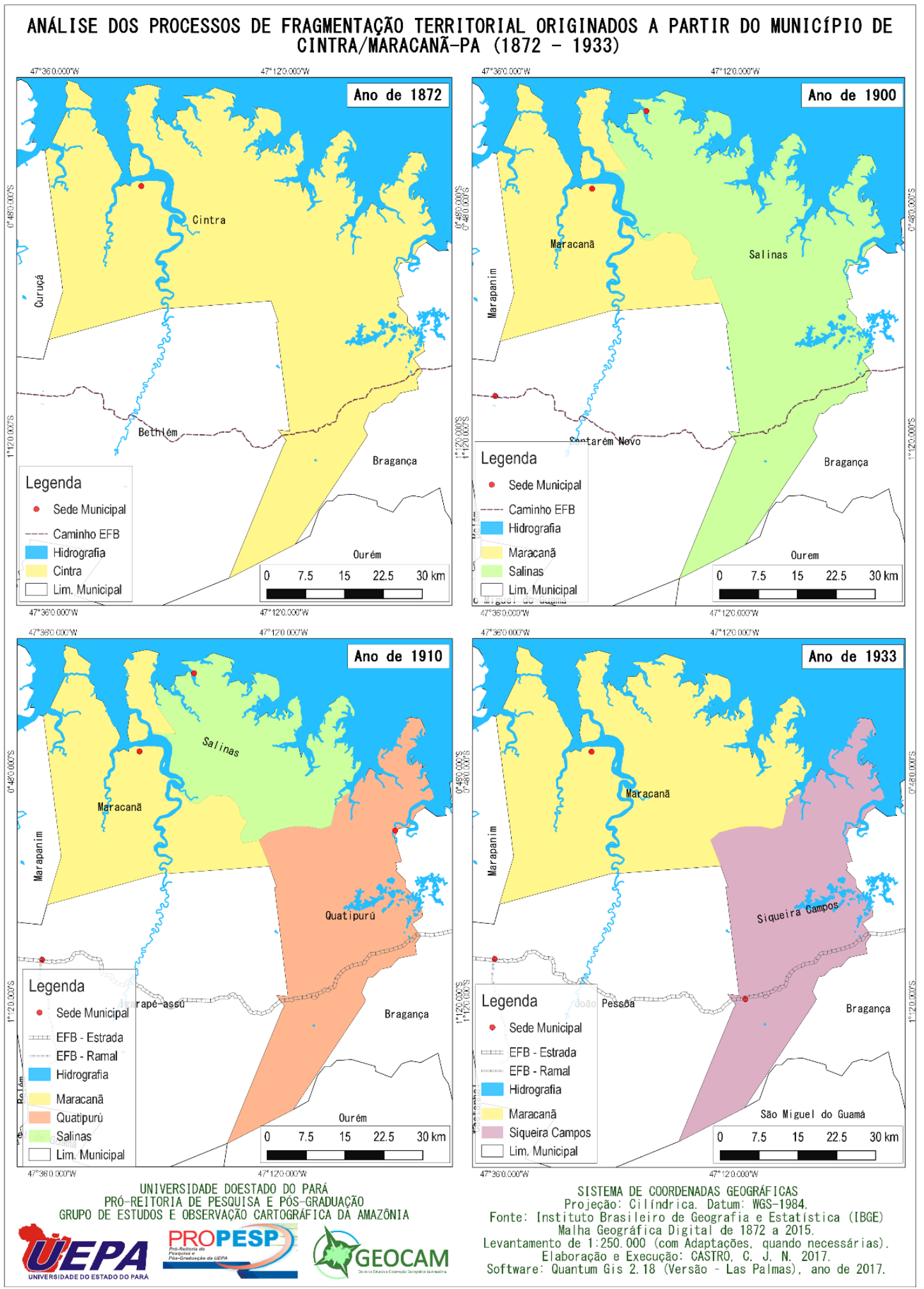

Mapa 3. Análise dos Processos de Fragmentação Territorial Originados a partir do Município de Cintra/Maracanã-PA (1872-1933). Fonte: GEOCAM (2017), com base em informações do IBGE (2014).

Conforme se verifica no mapa 3, com a extinção do município de Salinópolis e o remembramento ao município de Maracanã, este recuperou $922,72 \mathrm{~km}^{2}$. O papel exercido pela EFB foi preponderante para 
a consolidação de núcleos agrícolas já existentes, bem como para o surgimento de novos núcleos, necessários para o abastecimento da capital, a qual, de tempos em tempos, viveu sobressaltos com relação a gêneros de primeira necessidade (PENTEADO, 1973). Neste sentido, o movimento articulado de agentes territoriais de âmbito local e regional, a partir de dinâmicas produtivas concretas, tendem a gerar um processo de fragmentação territorial correlato à especialização produtiva do espaço. No caso da EFB, uma prótese territorial, ela alterou as dinâmicas de renda diferencial em relação à malha fluvial. Santos (1994, pp. 81-82) pondera que:

Pela forma como o capital fixo novo é distribuído no espaço, é possível discernir as articulações que se criam ou que se podem criar, neste ou naquele momento, tanto a articulação interna a cada subespaço como também aquelas entre subespaços. São ambas as articulações que vão explicar o movimento da urbanização e sua repartição no território.

Esse princípio de método auxilia a interpretação geográfica. É neste contexto de implantação desse sistema de engenharia (a EFB) que as cidades e vilas que tiveram seu desenvolvimento ligado aos cursos d'água e que não foram alcançadas começam a passar por um processo de estagnação ou mesmo retração econômica e política. A instalação dessa nova infraestrutura no sistema de transporte impactou diretamente o primeiro padrão de ocupação e organização espacial da Amazônia.

Na literatura acerca de sistema de transportes e organização espacial, é conhecida a série de alterações provocada pela chegada das rodovias, desde as alterações macroestruturais, conforme foi o caso da implantação da Rodovia Belém-Brasília (BR-010), cujas mudanças provocadas no território foram estudadas por Valverde e Dias (1967), e da Rodovia Transamazônica (BR-230), cujo processo de penetração de novas dinâmicas foi pesquisado por Velho (1972), a impactos em escalas menores, como mostram os estudos de Furtado (1987) que ilustram como a rede rodoviária modificou as faixas de uso do solo em Marapanim, provocando uma especialização produtiva, ou de Albuquerque (2003), que analisa como a rede rodoviária alterou a dinâmica do transporte rural-urbano em Abaetetuba, ilustrando o caso da comunidade Bom Jesus, baseada na malha hidrográfica, suplantada pela comunidade Murutinga, baseada na rede rodoviária.

Entrementes, para o Nordeste Paraense é necessário considerar que mudanças desse gênero ocorreram primeiramente com a mudança do modal hidroviário para o ferroviário, provocando alterações 
econômicas e político-administrativas, o que, posteriormente, seria reforçado com a alteração seguinte, para o modal rodoviário. Nos anos 1940, a mesorregião Nordeste Paraense possui seus municípios efetivamente integrados à capital por malha ferroviária. Assim, a circulação de pessoas, capitais e informações estavam disciplinados frente à densidade dos fluxos possíveis pela velocidade dos trilhos, marcando o segundo período de formação urbana, conforme a periodização de Ribeiro (2015), caracterizado pela hegemonia da malha ferroviária, conforme ilustra o mapa 4.

Não obstante, a formação espacial brasileira a partir dos anos 1950 e 1960, durante o Governo Juscelino Kubitschek (1956-1961), e de forma mais profunda, a partir da Ditadura Militar (1964-1985), viveu um novo projeto de Estado Nacional, ligado aos interessses da indústria automobilística internacional, a qual instalou montadoras em território nacional. Nesse momento, optou-se por abortar o projeto de integração territorial via ferrovia, em prol da integração rodoviária. Os rebatimentos espaciais no estado do Pará foram os desmontes na malha ferroviária e sua substituição pelo modal rodoviário.

É necessária uma ponderação acerca disso. Ao contrário de outras áreas da Amazônia ${ }^{8}$, onde a destruição da malha ferroviária provocou fortes alterações espaciais, no caso do Nordeste Paraense a malha rodoviária, grosso modo, suplantou a malha ferroviária como sua caudatária. Os trajetos rodoviários implantados seguiram os trajetos já estabelecidos pelas ferrovias, como foram os casos dos trajetos da rodovia BR-316 entre Belém e Castanhal, da rodovia PA-320 entre Castanhal e Igarapé-Açu, da rodovia PA-242 entre Igarapé-Açu e Capanema, e da rodovia BR-308 entre Capanema e Bragança, todos implantados sobre os trajetos da Estrada de Ferro de Bragança (EFB).

Mesmo na cidade de Belém, o trajeto da EFB deu lugar à Avenida Tito Franco (atual Avenida Almirante Barroso) (CRUZ, 1973), bem como o ramal ferroviário que ligava a vila de Pinheiro (atual Distrito de Icoaraci) à EFB cedeu o traçado para a construção da Avenida Augusto Montenegro (CASTRO, 2017). Desse modo, as mudanças notadas ocorreram mais no sentido de intensificar o que já havia sido

\footnotetext{
${ }^{8}$ De acordo com Cavalcante et al. (2011), no município de Porto Velho (RO), a derrocada da Ferrovia Madeira-Mamoré em prol da malha rodoviária (BR-364) implicou na ascensão do extrativismo mineral, com destaque para a garimpagem, em detrimento do extrativismo vegetal, então atividade hegemônica, o que por sua vez, implicou no surgimento de novos núcleos com destaque para a Vila das Araras, Embaúba e Palmeiral. Já na área estudada por Velho (1972), a desativação da Estrada de Ferro Tocantins (EFT), em 1973, que ligava a cidade Tucuruí (PA) ao Porto de Jatobal, em Imperatriz (MA) impactou não apenas em alterações de dinâmicas produtivas, mas trouxe severas implicações no comando político desta área, que antes cabia aos sócios da ferrovia, rapidamente substituídos pelos empresários e políticos ligados, de algum modo, aos novos objetos instalados, como a hidrelétrica de Tucuruí, inaugurada em 1985 (ROCHA, 2008).
} 
estabelecido estruturalmente pela EFB, com comunidades agrícolas, baseadas em minifúndios, fortemente asseguradas no abastecimento à cidade de Belém (MIRANDA, 2009).

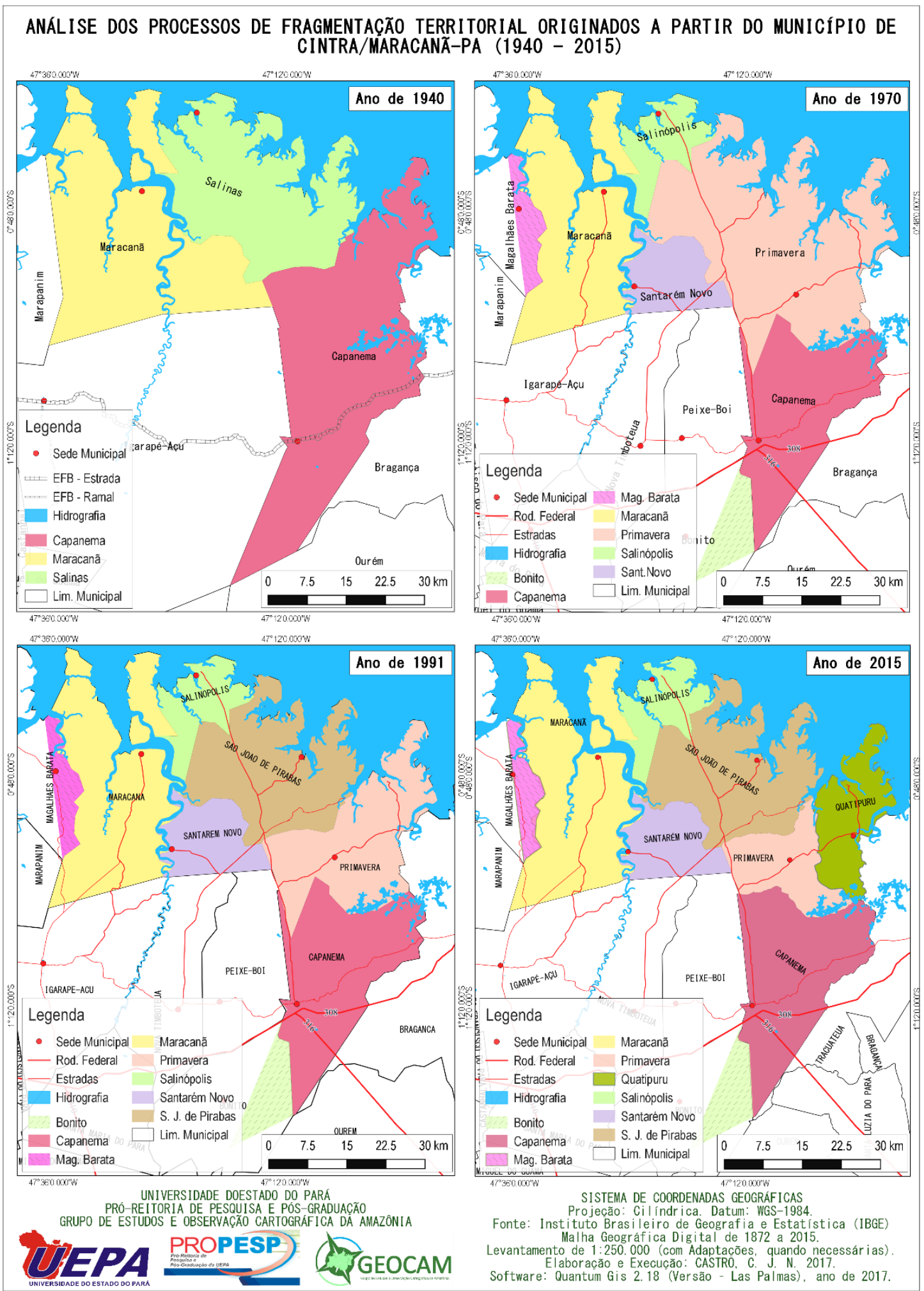

Mapa 4. Análise dos Processos de Fragmentação Territorial Originados a partir do Município de Cintra/Maracanã-PA (1940-2015). Fonte: GEOCAM (2017), com base em informações do IBGE (2014). 
É notório, porém, que a malha rodoviária acelerou os processos de emancipação política de municípios, pois, isto carreou uma série de produtos e serviços em direção às vilas que articulavam a produção rural, complexificando a divisão do trabalho (LOUREIRO, 1985; RIBEIRO, 2017), alterando, de qualquer modo, de forma profunda o arranjo espacial da hinterlândia de Belém. Com base nas interações espaciais marcadas pela expansão das rodovias, em substituição dos trilhos, observam-se alterações nos municípios originados a partir de Cintra/Maracanã.

Em 1970, quando é implantado de modo definitivo o padrão rodoviário de circulação nos municípios originados da fragmentação de Cintra/Maracanã, observa-se a aceleração do processo de fragmentação municipal a nordeste, com a emancipação do município de Primavera, acompanhando o processo que vai ocorrendo no município limítrofe, que de Siqueira Campos passa a se chamar Capanema. Em Capanema se localiza uma importante concentração de calcário, e partir daí, nessa cidade se concentraram uma série de serviços e comércios, induzidas pela indústria de mineração implantada, chegando ao ponto da cidade de Capanema atualmente se comportar como um centro mais dinâmico do que a tradicional cidade de Bragança (RIBEIRO, 2017).

No entanto, as fragmentações decorridas a partir de 1991, deram origem a municípios cujas suas sedes ficaram atreladas ao rio, como é o caso de Quatipuru refundado em 1994, a partir da fragmentação do limite territorial de Primavera. Como síntese do processo de fragmentação territorial, apresentam-se os dados abaixo.

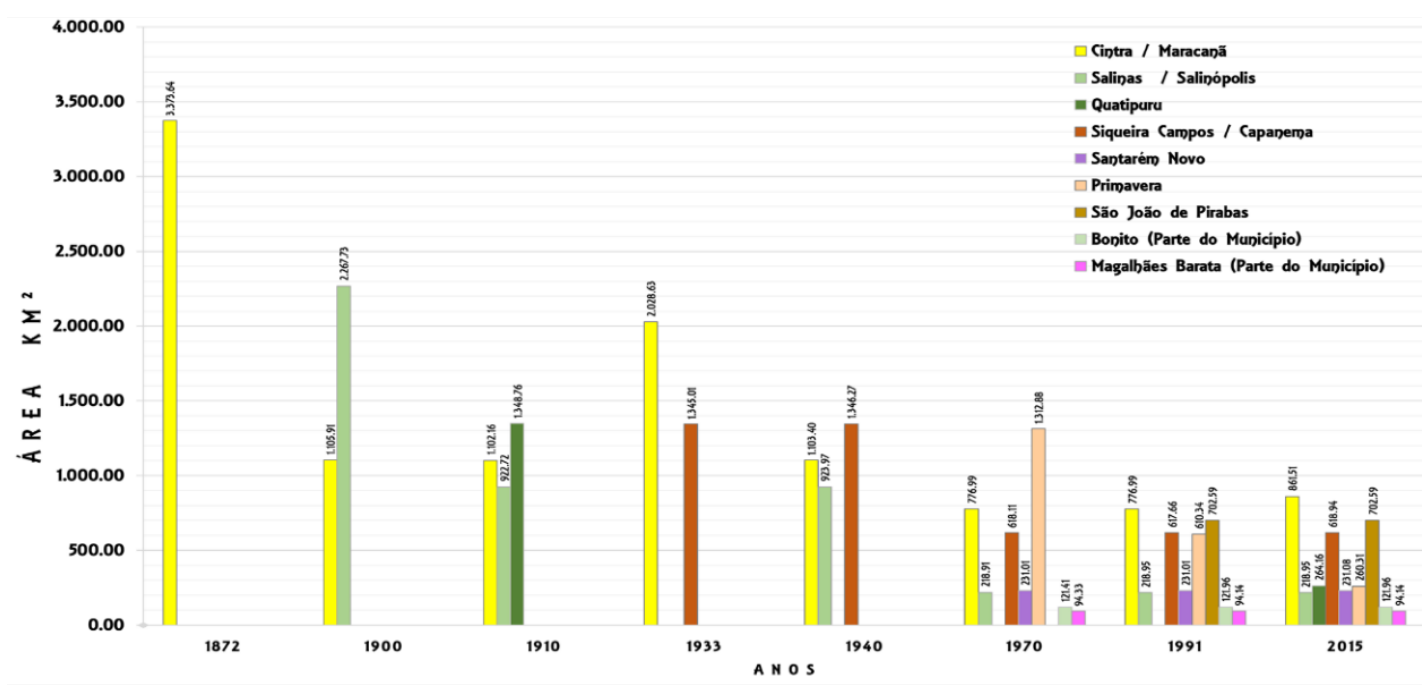

Gráfico 1. Síntese das perdas e acréscimos de área sofridos pelo município de Cintra/Maracanã. Fonte: GEOCAM (2017), com base em informações do IBGE (2014). 
No gráfico 1, é possível visualizar o processo de fragmentação do talhão territorial do município de Cintra/Maracanã e as subsequentes divisões territoriais dos municípios criados a partir deste. Ao comparar as representações cartográficas contidas nos mapas 3 e 4 somadas à análise do gráfico 1, ficam patentes as fragmentações a partir das mudanças nos eixos de circulação, a qual a região foi submetida, inicialmente pela inserção da rede ferroviária que se implantava na porção central do continente, a qual promoveu a primeira reestruturação nas relações entre municípios com alternância das sedes municipais que passaram a se situar na ponta dos trilhos. Com o fim da estrada de ferro e o implemento das rodovias se inicia uma nova dinâmica em termos de interação espacial e dinamismo das cidades.

\section{A REPRODUÇÃO DO ESPAÇO RURAL DE MARACANÃ}

Conforme já foi comentado, o êxodo rural no Nordeste Paraense ocorre predominantemente por fatores econômicos, com a estrutura fundiária baseada em minifúndios, ocupados por posseiros, cuja produção descapitalizada, sobretudo do roçado da mandioca, terminou por solapar muito rapidamente os solos, predominantemente latossolos amarelos (FURTADO, 1987). O município de Maracanã está diretamente implicado neste processo de minifundização, inclusive por ser ainda atualmente predominantemente um município rural.

\begin{tabular}{lrrrrr}
\hline Ano & \multicolumn{2}{l}{$\begin{array}{l}\text { População } \\
\text { Total }\end{array}$} & \multicolumn{2}{l}{$\begin{array}{l}\text { População } \\
\text { Urbana }\end{array}$} & \multicolumn{2}{l}{$\begin{array}{l}\text { População } \\
\text { Rural }\end{array}$} & \multicolumn{2}{l}{$\begin{array}{l}\text { Percentual } \\
\text { Urbano }\end{array}$} & \multicolumn{2}{l}{$\begin{array}{l}\text { Percentual } \\
\text { Rural }\end{array}$} \\
\hline 1991 & 21.340 & 8.186 & 13.154 & 38,36 & 61,64 \\
2000 & 27.571 & 11.712 & 15.859 & 42,48 & 57,52 \\
2010 & 28.376 & 11.656 & 16.720 & 41,08 & 58,92 \\
\hline
\end{tabular}

Tabela 1. População por situação de domicílio em Maracanã (PA). Fonte: IBGE (2011) adaptado pelo GEOCAM (2017).

Entrementes, o município de Maracanã apresenta-se com predominância de domicílios em situação rural. Nos últimos três censos do IBGE é possível visualizar que há aumento percentual da população urbana, mas a concentração da população rural se mantém estável nas três últimas décadas cobertas pelo recenseamento. 


\begin{tabular}{crrr}
\hline IDHM & \multicolumn{3}{c}{ ANOS } \\
& 1991 & 2000 & 2010 \\
\hline IDH - M & 0,313 & 0,40 & 0,570 \\
& & 6 & \\
IDH - M & 0,64 & 0,69 & 0,76 \\
Longevidade & 3 & 7 & 4 \\
IDH - M Educação & 0,111 & 0,215 & 0,454 \\
IDH - M Renda & 0,432 & 0,447 & 0,534 \\
\hline
\end{tabular}

Tabela 2. Índice de Desenvolvimento Humano (IDHM) de Maracanã (PA), com Nova Metodologia. Fonte: PNUD; IPEA (2011) adaptado pelo GEOCAM (2017).

Em termos de desenvolvimento humano, verifica-se que o IDH do município tem crescido ao longo das três últimas décadas. Quando analisados os números (já adequados à nova metodologia de aferição para efeito de comparação), o componente mais baixo do IDH persiste sendo a educação que, não obstante aumentou de 0,111 para 0,454 em duas décadas, sendo essa a maior alteração. Longevidade e renda tiveram aumento moderado entre 1991 e 2010 (Tabela 1).

Apesar do peso da população rural em Maracanã, quando analisado seu contexto mesorregional, cabe dizer que o crescimento demográfico trouxe impactos típicos da urbanização desigual brasileira, onde um circuito de trabalho intensivo e precarizado sustenta o circuito econômico formal (SANTOS, 2008). Neste sentido, os municípios amazônicos têm sido analisados pela literatura geográfica a partir da questão da desigualdade socioespacial. Para Rodrigues (2015), a desigualdade pode ser aferida através da distribuição dos serviços e equipamentos urbanos.

No caso de Maracanã, vê-se que apesar de sua origem estar ligada à malha hidrográfica, o abastecimento de água é um problema, materializando o que Bordalo (2017) nomeia de "paradoxo da água" na Amazônia. Conforme a Agência Nacional de Águas (ANA), o município de Maracanã possui 48,57\% de sua população atendida com rede geral de abastecimento de água, sendo que quando considerada a população rural, apenas $63,58 \%$ desta possui acesso à rede geral de abastecimento de água (ANA, 2013).

\begin{tabular}{|c|c|c|c|c|}
\hline \multirow[t]{2}{*}{ Ano } & \multirow[t]{2}{*}{ Total } & \multicolumn{3}{|c|}{ Forma de abastecimento de água } \\
\hline & & $\begin{array}{l}\text { Rede Geral de } \\
\text { Distribuição }\end{array}$ & $\begin{array}{c}\text { Poço ou Nascente na } \\
\text { Propriedade }\end{array}$ & Outra \\
\hline 1991 & 4.941 & 1.794 & 1.022 & 2.125 \\
\hline 2000 & 5.489 & 3.103 & 1.560 & 826 \\
\hline 2010 & 6.788 & 4.316 & 1.132 & 1.340 \\
\hline
\end{tabular}


Tabela 3. Domicílios particulares permanentes, por forma de abastecimento de água em Maracanã (PA). Fonte: IBGE (2011) adaptado pelo GEOCAM (2017).

Os dados do IBGE (Tabela 3), em relação aos da ANA (2013) permitem acompanhar trajetórias, devido à continuidade da série, onde é possível visualizar o avanço da cobertura dos domicílios pela rede geral de abastecimento, mas também a persistência de um número elevado de domicílios que realiza o abastecimento por outras vias. Além do abastecimento hídrico, o saneamento básico é uma questão chave em Maracanã.

Os dados levantados nos três últimos censos do IBGE (tabela 4) dão conta de que apenas 46 domicílios (0,67\% do total) possuía acesso à rede geral de esgoto ou rede pluvial em 2010. Não obstante, em 1991 nenhum domicílio possuía acesso, e em 2000, apenas cinco domicílios o possuíam. A grande maioria recorre ao tradicional sistema de fossa séptica ou outro sistema de solução individual. O número de domicílios sem nenhum de banheiro ou sanitário vem diminuindo pouco desde 1991. Os dados apontam uma situação crítica.

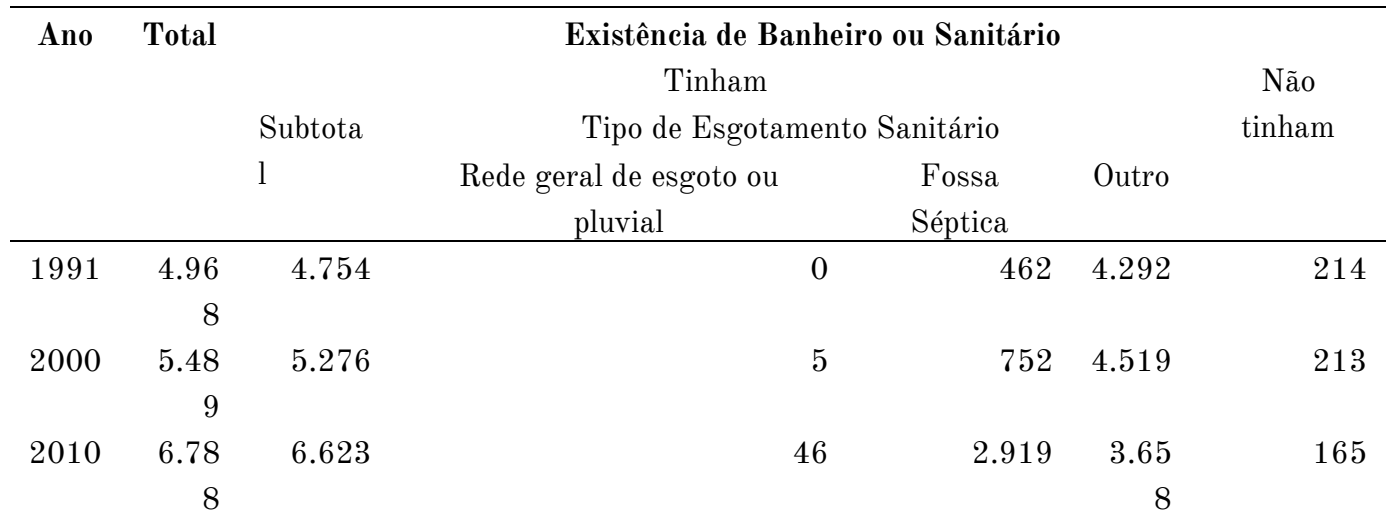

Tabela 4. Domicílios particulares permanentes, por existência de banheiro ou sanitário e tipo de esgotamento sanitário em Maracanã (PA). Fonte: IBGE (2011) adaptado pelo GEOCAM (2017).

Os dados mostram que Maracanã é um município com predominância da população rural, a qual está vivendo dificuldades do ponto dos serviços, com desenvolvimento social regular, com uma concentração urbana que não tem significado acesso a direitos. Complementando o quadro socioeconômico, em 2010, conforme o IBGE (2010), apenas 29,98\% dos domicílios possuíam acesso à coleta de lixo, porém, 91,82\% já possuí acesso à energia elétrica. Em 2000, apenas 54,58\% dos domicílios de Maracanã o possuíam. Esse resultado deriva diretamente do Programa Luz para Todos, executado durante os 
governos Lula-Dilma. Com relação à força de trabalho, a administração pública responde pelo maior estoque de empregos do município, entre 2005 e 2015, aumentando sua concentração nesse quesito ao longo desta década (tabela 5).

\begin{tabular}{lcccccccccccc}
\hline Setor & \multicolumn{10}{c}{ Anos } \\
\cline { 2 - 11 } & 2005 & 2006 & 2007 & 2008 & 2009 & 2010 & 2011 & 2012 & 2013 & 2014 & 2015 \\
\hline Indústria & - & 1 & 4 & - & - & - & - & - & - & 4 & $\boldsymbol{7}$ \\
Serviços Ind. Utilidade & 3 & 1 & 1 & 1 & 1 & 1 & 1 & 1 & - & - & - \\
Pública & & & & & & & & & & & \\
Construção Civil & - & - & - & - & - & - & - & - & $\mathbf{5}$ & 2 & 2 \\
Comércio & 19 & 21 & 44 & 36 & 59 & 40 & 35 & 45 & $\mathbf{6 8}$ & 59 & 60 \\
Serviços & 10 & 15 & 11 & 13 & 15 & 19 & 17 & 43 & 59 & $\mathbf{7 9}$ & 20 \\
Adm. Pública & 999 & 917 & 884 & 1.16 & 1.295 & 1.750 & 1.711 & 1.36 & $\mathbf{1 . 9 5 0}$ & 1.85 & 1.80 \\
& & & & 2 & & & & 2 & 6 & 8 & 0 \\
Agropecuária & $\mathbf{1 6}$ & 14 & 7 & 8 & 9 & 6 & 6 & 6 & 6 & - & - \\
Total & 1.047 & 969 & 951 & 1.220 & 1.379 & 1.81 & 1.770 & 1.457 & $\mathbf{2 . 0 8}$ & 2.017 & 1.90 \\
& & & & & & 6 & & & $\mathbf{8}$ & 8 \\
\hline
\end{tabular}

Tabela 5. Estoque de emprego segundo o setor de atividade econômica em Maracanã (PA). Fonte: MTE-RAIS (2016) adaptado pelo GEOCAM (2017).

Assim, o estoque de empregos é baseado nos empregos formais, que deixam registros. O que se vê primeiramente é o quão baixo é o número de empregos formais no município de Maracanã. Muito atrás da administração pública, o setor que mantém o maior estoque de empregos é o comércio, seguido pelo setor de serviços. Comércio e serviços (incluindo os da administração pública) podem ser apontados como os setores que têm capacidade de polarização ao nível dessas cidades da rede urbana da Amazônia Oriental (RIBEIRO, 2017).

Apesar do peso da população rural, a agropecuária responde por um valor muito baixo no estoque de empregos. Esse dado se refere, como dito, aos empregos formais. Como se verá, a atividade agrícola é responsável pelo sustento da maior parte das famílias de Maracanã. O setor de serviços e comércio, animado pelo setor público, é quem mantém também o maior valor adicionado ao PIB municipal de Maracanã, tendo crescido dos 36 milhões de reais em 2004, chegando a pouco mais de 120 milhões em 2014 (gráfico 2). 


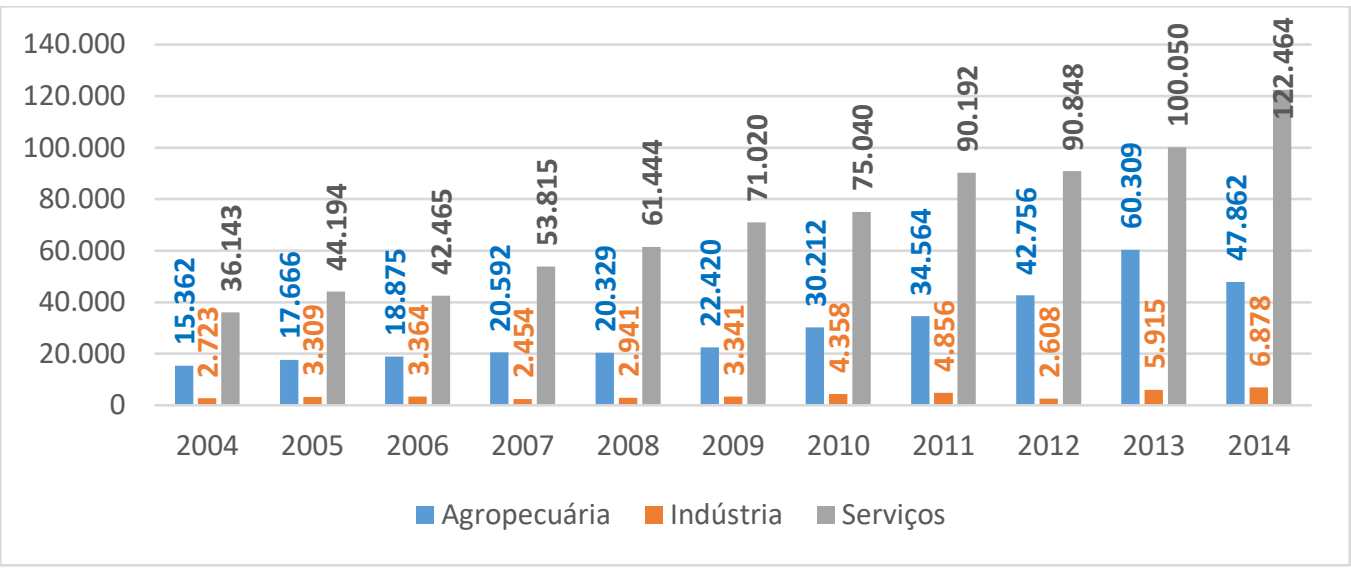

Gráfico 1. Valor Adicionado Bruto a Preço Básico Corrente por Setor, em Maracanã (PA), em mil reais. Fonte: FAPESPA; IBGE (2015) adaptado pelo GEOCAM (2017).

No mesmo período, o setor agropecuário apresentou leve ascensão entre 2010 e 2013, enquanto que a indústria mantém participação minúscula em todo o período (gráfico 2). Contudo, essa setorização econômica não é suficiente para compreender as dinâmicas territoriais do município de Maracanã. Mantendo a tradição da colonização erigida durante a hegemonia da EFB, trata-se de um município agrícola, com destaque para a agricultura familiar.

\begin{tabular}{cccccccccccc}
\hline Produto & $\mathbf{2 0 0}$ & $\mathbf{2 0 0}$ & $\mathbf{2 0 0}$ & $\mathbf{2 0 0}$ & $\mathbf{2 0 0 9}$ & $\mathbf{2 0 1 0}$ & $\mathbf{2 0 1 1}$ & $\mathbf{2 0 1 2}$ & $\mathbf{2 0 1 3}$ & $\mathbf{2 0 1 4}$ & $\mathbf{2 0 1}$ \\
& $\mathbf{5}$ & $\mathbf{6}$ & $\boldsymbol{7}$ & $\mathbf{8}$ & & & & & & & $\mathbf{5}$ \\
\hline Abacaxi & 60 & 50 & 50 & $\mathbf{6 7}$ & 20 & 20 & 20 & 20 & 3 & 3 & 2 \\
Arroz & $\mathbf{1 7 0}$ & 127 & 127 & 60 & 60 & 32 & 32 & 32 & 32 & 32 & 28 \\
Feijão & 360 & 380 & $\mathbf{4 0 0}$ & 50 & 50 & 135 & 160 & 160 & 160 & 160 & 30 \\
Malva & 46 & 46 & - & - & - & - & - & - & - & - & - \\
Mandioc & 971 & 980 & 980 & 800 & $\mathbf{1 . 0 0 0}$ & $\mathbf{1 . 0 0 0}$ & $\mathbf{1 . 0 0 0}$ & $\mathbf{1 . 0 0 0}$ & $\mathbf{1 . 0 0 0}$ & $\mathbf{1 . 0 0 0}$ & 800 \\
a & & & & & & & & & & & \\
Melancia & 60 & 82 & 82 & 82 & 82 & 90 & 110 & 110 & 110 & 110 & $\mathbf{1 2 0}$ \\
Milho & 328 & $\mathbf{4 1 0}$ & $\mathbf{4 1 0}$ & 200 & 200 & 200 & 230 & 230 & 230 & 230 & 180 \\
\hline
\end{tabular}

Tabela 1. Área Colhida dos Principais Produtos das Lavouras Temporárias em Maracanã (PA), em ha. Fonte: IBGE (2016) adaptado pelo GEOCAM (2017).

Assim, conforme os dados da tabela 6 é possível ter uma dimensão do quanto da área municipal é ocupada pela atividade agrícola. A malva que consorciada com a mandioca ocupou uma vasta área do Nordeste Paraense nos anos 1950, conforme Valverde e Dias (1961) despareceu de Maracanã após 2007. A área ocupada pelos cultivos de abacaxi vem diminuindo bruscamente ao longo da década 2005-2015. A área ocupada pelo arroz também apresentou diminuição, enquanto que teve leve expansão a área dedicada aos cultivos de melancia. 
Em dez anos a produção de milho em Maracanã apresentou um pequeno declínio, ao passo que os cultivos de mandioca ocuparam durante o período inteiro a maior parte da área plantada por cultivos temporários. Na realidade, a mandioca é a cultura mais plantada em Maracanã, rivalizando com a cultura permanente do Coco da Bahia, a qual entre 2005 e 2010 ocupou 500 hectares de área plantada, porém, a partir de 2011, registrou uma grande diminuição (tabela 7).

\begin{tabular}{cccccccccccc}
\hline Produto & $\mathbf{2 0 0}$ & $\mathbf{2 0 0}$ & $\mathbf{2 0 0}$ & $\mathbf{2 0 0}$ & $\mathbf{2 0 0}$ & $\mathbf{2 0 1}$ & $\mathbf{2 0 1}$ & $\mathbf{2 0 1}$ & $\mathbf{2 0 1}$ & $\mathbf{2 0 1}$ & $\mathbf{2 0 1}$ \\
& $\mathbf{5}$ & $\mathbf{6}$ & $\mathbf{7}$ & $\mathbf{8}$ & $\mathbf{9}$ & $\mathbf{0}$ & $\mathbf{1}$ & $\mathbf{2}$ & $\mathbf{3}$ & $\mathbf{4}$ & $\mathbf{5}$ \\
\hline Banana & 7 & 12 & 12 & 12 & $\mathbf{2 4}$ & $\mathbf{2 4}$ & $\mathbf{2 4}$ & $\mathbf{2 4}$ & 10 & 10 & 10 \\
Coco da Bahia & $\mathbf{5 0 0}$ & $\mathbf{5 0 0}$ & $\mathbf{5 0 0}$ & $\mathbf{5 0 0}$ & $\mathbf{5 0 0}$ & $\mathbf{5 0 0}$ & 20 & 20 & 20 & 20 & 25 \\
Dendê & 100 & 100 & 100 & 100 & 100 & 100 & 100 & 100 & 100 & 100 & $\mathbf{1 2 0}$ \\
Laranja & 10 & 10 & 10 & 10 & 10 & 22 & 22 & 22 & 22 & 22 & $\mathbf{2 9}$ \\
Mamão & - & - & - & - & - & - & - & - & - & - & 10 \\
Maracujá & 250 & 550 & $\mathbf{6 0 0}$ & 300 & 350 & 350 & 300 & 300 & 12 & 12 & 25 \\
Pimenta-do- & $\mathbf{1 3 5}$ & $\mathbf{1 3 5}$ & $\mathbf{1 3 5}$ & $\mathbf{1 3 5}$ & $\mathbf{1 3 5}$ & 100 & 100 & 100 & 35 & 35 & 45 \\
reino & & & & & & & & & & & \\
Urucum & - & - & - & - & - & - & - & - & - & 2 & 2 \\
\hline
\end{tabular}

Tabela 2. Área Colhida dos Principais Produtos das Lavouras Permanentes em Maracanã (PA), em ha. Fonte: IBGE (2016) adaptado pelo GEOCAM (2017).

Enquanto porção do Baixo Tocantins, especialmente os vales dos rios Moju e Acará têm visto uma verdadeira expansão da dendeicultura (CÓRDOBA et al, 2018), o que leva alguns autores a falarem em “descampenização” provocada pela palma (NAHUM; SANTOS, 2014), o município de Maracanã possui uma produção antiga de palma, cujo vetor de expansão se deu a partir do município vizinho de IgarapéAçu. Em termos gerais, percebe-se, conforme a tabela 7, que a área ocupada por cultivos permanentes diminui bastante após 2010 .

A pimenta-do-reino que também teve sua hegemonia nos anos 1950 como principal produto permanente plantado no Nordeste Paraense, em Maracanã passa a ocupar uma área bem restrita a partir de 2013. Ainda maior é a diminuição da área de plantação de maracujá. Durante todo o período 2005-2015 há uma pequena área plantada com banana e laranja, sendo que dois cultivos tradicionais na região só apresentam números em anos recentes, o urucum apenas em 2014 e 2015, e o mamão apenas em 2015.

\begin{tabular}{cccccccccccc}
\hline Produto & $\mathbf{2 0 0 5}$ & $\mathbf{2 0 0 6}$ & $\mathbf{2 0 0 7}$ & $\mathbf{2 0 0 8}$ & $\mathbf{2 0 0 9}$ & $\mathbf{2 0 1 0}$ & $\mathbf{2 0 1 1}$ & $\mathbf{2 0 1 2}$ & $\mathbf{2 0 1 3}$ & $\mathbf{2 0 1 4}$ & $\mathbf{2 0 1 5}$ \\
\hline Abacaxi & 600 & 500 & 500 & $\mathbf{1 . 3 4 0}$ & 400 & 400 & 400 & 400 & 60 & 60 & 40
\end{tabular}




\begin{tabular}{|c|c|c|c|c|c|c|c|c|c|c|c|}
\hline Arroz & 119 & 89 & 89 & 42 & 30 & 24 & 16 & 16 & 16 & 16 & 14 \\
\hline Feijão & 252 & 266 & 280 & 35 & 35 & 95 & 112 & 112 & 112 & 112 & 21 \\
\hline Malva & 46 & 46 & - & - & - & - & - & - & - & - & - \\
\hline Mandioc & 9.710 & 9.80 & 9.80 & 8.25 & 8.00 & 10.000 & 10.000 & 10.000 & 10.000 & 10.000 & 8.00 \\
\hline $\mathrm{a}$ & & 0 & 0 & 0 & 0 & & & & & & 0 \\
\hline Melancia & 1.08 & 1.47 & 1.47 & 1.47 & 1.47 & 1.620 & 1.980 & 1.980 & 1.980 & 1.980 & 2.40 \\
\hline & 0 & 6 & 6 & 6 & 6 & & & & & & 0 \\
\hline Milho & 184 & 230 & 230 & 120 & 120 & 60 & 138 & 138 & 138 & 138 & 108 \\
\hline
\end{tabular}

Tabela 3. Quantidade Produzida dos Principais Produtos das Lavouras Temporárias em Maracanã (PA), em t. Fonte: IBGE (2016) adaptado pelo GEOCAM (2017).

Quando a ponderação se dá acerca da quantidade produzida, percebe-se com maior facilidade que a mandioca e o cultivo mais importante de Maracanã, variando entre oito e dez mil toneladas entre 2005 e 2015. Em segundo lugar, entre os cultivos temporários, está a melancia, com uma produção crescente no mesmo período, chegando a mais de duas mil toneladas em 2015. A queda nas produções de arroz e de abacaxi são bastante acentuadas nesse período, ao passo que feijão e milho alternam anos bons e anos ruins.

\begin{tabular}{cccccccccccc}
\hline Produto & $\mathbf{2 0 0 5}$ & $\mathbf{2 0 0 6}$ & $\mathbf{2 0 0 7}$ & $\mathbf{2 0 0 8}$ & $\mathbf{2 0 0 9}$ & $\mathbf{2 0 1 0}$ & $\mathbf{2 0 1 1}$ & $\mathbf{2 0 1 2}$ & $\mathbf{2 0 1 3}$ & $\mathbf{2 0 1 4}$ & $\mathbf{2 0 1 5}$ \\
\hline Banana & 49 & 84 & 84 & 84 & $\mathbf{1 6 8}$ & $\mathbf{1 6 8}$ & $\mathbf{1 6 8}$ & $\mathbf{1 6 8}$ & 70 & 70 & 75 \\
Coco da Bahia & $\mathbf{3 . 0 0 0}$ & $\mathbf{3 . 0 0 0}$ & $\mathbf{3 . 0 0 0}$ & $\mathbf{3 . 0 0 0}$ & $\mathbf{3 . 0 0 0}$ & $\mathbf{3 . 0 0 0}$ & $\mathbf{3 . 0 0 0}$ & 300 & 300 & 300 & 300 \\
Dendê & $\mathbf{1 . 5 0 1}$ & $\mathbf{1 . 5 0 1}$ & $\mathbf{1 . 5 0 1}$ & $\mathbf{1 . 5 0 1}$ & $\mathbf{1 . 5 0 1}$ & $\mathbf{1 . 5 0 1}$ & 1.100 & 1.100 & 1.100 & 1.100 & 1.320 \\
Laranja & 133 & 133 & 133 & 133 & 133 & 293 & 293 & 293 & 293 & 293 & $\mathbf{3 4 8}$ \\
Mamão & - & - & - & - & - & - & - & - & - & - & 120 \\
Maracujá & 2.500 & 5.500 & $\mathbf{6 . 0 0}$ & 3.000 & 3.500 & 3.500 & 3.000 & 3.000 & 120 & 120 & 250 \\
& & & $\mathbf{0}$ & & & & & & & & \\
Pimenta-do- & $\mathbf{1 8 9}$ & $\mathbf{1 8 9}$ & $\mathbf{1 8 9}$ & $\mathbf{1 8 9}$ & $\mathbf{1 8 9}$ & 140 & 160 & 160 & 160 & 105 & 108 \\
reino & & & & & & & & & & & \\
Urucum & - & - & - & - & - & - & - & - & - & 2 & 1
\end{tabular}

Tabela 4. Quantidade Produzida dos Principais Produtos das Lavouras Permanentes em Maracanã (PA), em t. Fonte: IBGE (2016) adaptado pelo GEOCAM (2017).

Em relação à quantidade produzida dos principais produtos oriundos de lavouras permanentes, a principal queda é a da produção do Coco da Bahia. Uma redução de 90\%, pois, entre 2005 e 2011 o município de Maracanã produziu três mil toneladas deste produto, a partir de 2012, a produção se mantém em 300 toneladas. A produção de dendê mantém uma constante no período, com leve queda a partir de 2011. A produção de laranja apresenta leve aumento a partir de 2010. 
A diminuição da área da produção de maracujá (tabela 7), manifesta-se de forma impressionante na queda de produtividade do maracujá em Maracanã (tabela 9). 0 município de Maracanã produziu seis mil toneladas de maracujá em 2007, porém, sete anos depois, produziu somente 120 toneladas do produto. Já a produção de mamão, iniciada em 2015, apresentou uma colheita de 120 toneladas naquele ano.

\begin{tabular}{ccccccccccccc}
\hline $\begin{array}{c}\text { Tipo de } \\
\text { Rebanho }\end{array}$ & $\mathbf{2 0 0 5}$ & $\mathbf{2 0 0 6}$ & $\mathbf{2 0 0 7}$ & $\mathbf{2 0 0 8}$ & $\mathbf{2 0 0 9}$ & $\mathbf{2 0 1 0}$ & $\mathbf{2 0 1 1}$ & $\mathbf{2 0 1 2}$ & $\mathbf{2 0 1 3}$ & $\mathbf{2 0 1 4}$ & $\mathbf{2 0 1 5}$ \\
\hline Bovino & 3.472 & $\mathbf{3 . 5 6 9}$ & 2.780 & 2.791 & 2.849 & 2.596 & 2.691 & 2.816 & 3.306 & 2.768 & 2.650 \\
Suíno & 142 & 153 & 887 & $\mathbf{9 0 0}$ & 76 & 48 & 42 & 35 & 48 & 55 & 94 \\
Bubalino & 8 & 8 & 8 & 10 & 3 & - & 6 & 9 & 11 & 14 & $\mathbf{1 8}$ \\
Equino & 232 & $\mathbf{2 4 0}$ & 230 & 230 & 100 & 84 & 126 & 65 & 72 & 41 & 35 \\
Asinino & $\mathbf{1 0}$ & 10 & 10 & 10 & 1 & - & 1 & 3 & - & - & - \\
Muar & $\mathbf{3 2}$ & 30 & 25 & 25 & 5 & 11 & 13 & 10 & - & - & - \\
Ovino & 136 & 130 & 130 & 130 & 7 & 126 & 177 & $\mathbf{2 3 3}$ & 167 & 146 & 14 \\
Caprino & 91 & 120 & 120 & 125 & 43 & 60 & $\mathbf{4 7 3}$ & 125 & 50 & 43 & 80 \\
Galináceos - & 17.77 & 17.75 & 10.61 & 10.60 & 9.560 & 9.080 & 8.172 & 8.490 & 10.14 & 11.38 & $\mathbf{7 7 . 5 7}$ \\
Total & 9 & 0 & 3 & 0 & & & & & 5 & 5 & $\mathbf{5}$ \\
Galináceos - & 3.158 & $\mathbf{3 . 2 1 4}$ & 1.872 & 1.800 & 1.600 & 1.500 & 1.350 & 1.420 & 1.560 & 1.714 & 1.850 \\
Galinhas & & & & & & & & & & 24 & 25 & 25 \\
Vacas & $\mathbf{3 5 4}$ & 350 & 330 & 330 & 336 & 300 & 300 & 20 & 24 & \\
Ordenhadas & & & & & & & & & & \\
\hline
\end{tabular}

Tabela 5. Principais Rebanhos Existentes em Maracanã (PA). Fonte: IBGE (2016) adaptado pelo GEOCAM (2017).

Com relação à pecuária, atividade também importante no município de Maracanã, o rebanho bovino é intermediário, havendo no período de 2005 a 2010, uma média 2.500 cabeças de gado, compatível com a área disposta para pastos no município. Chama a atenção o volume pequeno de gado suíno. Com relação ao extrativismo vegetal, é necessário dizer que os índices até 2002 ainda contavam com uma pequena produção de látex, a qual desaparece nas estatísticas após 2003. No período 2005-2010, há a aparição crescente da produção de açaí, o qual ainda é categorizado pelo IBGE como atividade extrativista, embora haja estudos que questionam se o açaí, do modo como vem sendo desenvolvido no Pará, não pode também ser considerado uma monocultura (TAGORE, 2017).

\begin{tabular}{lccccccccccc}
\hline $\begin{array}{l}\text { Produt 2005 } \\
\text { o }\end{array}$ & 2006 & 2007 & 2008 & 2009 & 2010 & 2011 & 2012 & 2013 & 2014 & 2015 \\
\hline $\begin{array}{l}\text { Alimentícios } \\
\text { Açaí }\end{array}$ & - & - & 7 & 14 & 7 & 7 & 7 & 8 & 8 & 10 & 10
\end{tabular}




\begin{tabular}{|c|c|c|c|c|c|c|c|c|c|c|c|}
\hline \multicolumn{12}{|c|}{ Madeiras } \\
\hline Carvão & 75 & 74 & 74 & 80 & 70 & 63 & 57 & 53 & 51 & 45 & 40 \\
\hline \multicolumn{12}{|l|}{ Vegetal } \\
\hline Lenha & 27.089 & 27.76 & 27.760 & 30.000 & 26.65 & 24.500 & 22.050 & 20.000 & 18.000 & 12.000 & 10.000 \\
\hline & & 6 & & & 0 & & & & & & \\
\hline
\end{tabular}

Tabela 6. Quantidade Produzida pelo Extrativismo Vegetal em Maracanã (PA), em t. Fonte: IBGE (2016) adaptado pelo GEOCAM (2017).

Maracanã ainda possui uma boa parte de sua cobertura vegetal em forma de vegetação florestal, e também uma grande área de vegetação secundária, o que possibilita os altos números revelados na extração de lenha, com auge em 2008 na década 2005-2015. Contudo, duas importantes atividades estão ausentes das estatísticas. A atividade pesqueira, bem como o extrativismo animal, em geral. As estatísticas oficiais e detalhas sobre a pesca foram descontinuadas após a extinção da antiga Superintendência do Desenvolvimento da Pesca (SUDEPE), em 1992. Durante o Governo Lula (20032010), o Instituto Brasileiro do Meio Ambiente e dos Recursos Naturais Renováveis (IBAMA), e posteriormente, o Ministério da Pesca e da Aquicultura (MPA), produziram uma nova série estatística, mas sem a possibilidade de acompanha-la ao nível dos municípios.

\section{CONSIDERAÇÕES FINAIS}

Para entender o processo de colonização e ocupação no Nordeste Paraense é essencial apontar a importância dos primeiros núcleos que surgiram com aportes fluviais para que fossem estabelecidas estruturas com vistas a inserção dos lusitanos na Amazônia. Esses colonizadores conseguiram cooptar os nativos, amansados pelos religiosos, para atender seus fins em busca de resguardar essa parcela territorial litorânea brasileira, por conseguinte, espacializar-se utilizando os rios como circulação em busca de conexões entre os núcleos principais. Após consolidada as incursões marítimas e fluviais com a estruturação de núcleos costeiros estratégicos, dentre eles, Maracanã, o cenário se tornara favorável para que fosse feita investida rumo ao interior da região.

Com vistas à ampliação da colonização os agentes daquele período áureo pelo qual perpassava a economia paraense devido à borracha, permitiram um projeto macro que viabilizasse a ampla colonização, a ocupação e o fluxo regional de pessoas e produtos, direcionados principalmente a capital, Belém. Nesse 
sentido, no final do século XIX começou-se a delinear a frente expansionista via Estrada de Ferro de Bragança que traria um avanço nas atividades agrícolas, principalmente com o cultivo da mandioca, devido à ocupação de pequenos lotes pelos migrantes oriundos principalmente do Nordeste Brasileiro, apesar do ceticismo da elite local que preferia migrantes europeus devido à utilização de técnicas mais sofisticadas.

Com esse implemento, também se iniciou o processo de fragmentação territorial do Nordeste Paraense apresentando uma nova configuração espacial com vistas as intencionalidades dos agentes territoriais tanto no âmbito local quanto regional. Nesse sentido, alguns municípios, como Maracanã, importante no período embrionário da colonização da Amazônia, subsidiado pela circulação fluvial, foi afetado pelas inúmeras possibilidades de fragmentação materializando o padrão intermediário com ênfase na circulação pela ferrovia, vetor esse que traria alternativas na acessibilidade e abastecimento aos núcleos localizados no percurso entre Belém e Bragança até meados do século XX.

Com interesses políticos e econômicos começou-se a fluir o processo de fragmentação dos municípios a partir de Maracanã. Com essa dinâmica administrativa, também paulatinamente, ocorre a mudança do modal de circulação de pessoas, mercadorias e informações, que iniciara com o hidroviário perpassando para o ferroviário e com vistas a entrada do capital internacional, começa o processo de integração pela malha rodoviária a partir da década de 1960.

O sistema de transporte rodoviário trouxe consigo muitas contradições, que é essência do sistema vigente. Por outro lado, conseguiu comprimir o tempo em relação a espacialidade acompanhando o movimento nas diversas escalas, ampliando as interações espaciais e o dinamismo para a transformação do espaço urbano. E, a partir de Maracanã, consolida-se de fato esse processo de fragmentação, subdivisão e emancipação da porção territorial litorânea do Nordeste Paraense com destaque para Salinópolis como polo turístico e Capanema, importante centro comercial regional.

A reprodução do espaço rural de Maracanã esteve vinculada aos interesses dos agentes hegemônicos de outrora que tinha perfil diferenciado dos agentes de hoje. A economia local é o fator principal que 
dinamiza as questões socioespaciais. Nesse cenário, merece destaque os domicílios rurais que representam $61,64 \%$ e mantém a expressividade da população rural que faz parte desse processo de estagnação ou retração onde a má distribuição dos serviços e a ausência de equipamentos urbanos fragilizam a busca por um desenvolvimento mais plausível, solapando a educação, o saneamento básico entre outros.

Em relação ao emprego em Maracanã, merece destaque os empregos capitaneados pela administração pública, incluída no segmento dos serviços. Aliás, este e o comércio polariza os empregos formais. Ressalta-se ainda que as atividades provenientes da agricultura são responsáveis pela segurança alimentar da maioria da população, enquanto que as atividades relacionadas aos setores de serviços e comércio contribuem para elevar paulatinamente o PIB municipal, que evolui de 36 milhões em 2004 para de 120 milhões em 2014.

Apesar de o município ser oriundo do primeiro padrão de ocupação amazônico que tinha o rio como circulação e a pesca como atividade principal, hoje a economia é voltada para a agricultura familiar, herança do período ferroviário e, atualmente do rodoviário que contribuiu para as transformações ocorridas no espaço local. Logo, é perceptível a minifundização voltada para as lavouras temporárias e permanentes, principalmente na parte mais interior do município, enquanto que nas calhas dos principais rios destaca-se a pesca e o extrativismo.

Nesse dualismo das lavouras, em relação ao primeiro grupo, destaca-se o cultivo da mandioca, que mantivera um patamar elevado entre 2005 e 2015 fortalecendo a fabricação da farinha, produto essencial do paraense que se origina dessa cultura. Ainda nesse grupo, a melancia, cultura de ciclo rápido, se sobressai pelo imediatismo que vislumbra no retorno econômico para o produtor enquanto surgem a colheita das culturas de ciclo mais longo. No outro grupo, destaque para o coco da Bahia, cultura que teve seu auge entre 2005 e 2010, mantendo nesse período um patamar de 500 hectares plantados, porém, depois reduziu drasticamente. 0 maracujá também sofreu forte queda de área plantada e quantidade produzida depois de nível expressivo na segunda metade dos anos 2000. Em termos gerais, 
houve um declínio de áreas cultivadas e quantidade produzida tanto das culturas temporárias quanto das permanentes.

Dessa forma, não se pode considerar a reprodução do modo de vida rural no espaço urbano apenas pelo víeis da produção agrícola, característica presente, porém, não é a única. Precisa-se enxergar outras atividades que contemplam relações pertinentes a um todo. Logo, a ruralidade na urbanidade não se configura apenas em um aspecto econômico, mas também agrega valores sociais e culturais sem alijar os resquícios históricos e tradicionais.

Nesse contexto, para entender esse processo de dinamismo territorial e a reprodução espacial é necessário ter um discernimento relevante sobre as intencionalidades conduzidas pelos agentes hegemônicos locais que historicamente possibilitaram transformações socioespaciais de acordo com seus interesses políticos e econômicos potencializados de forma articulada no controle da produção do espaço. Diante disso, é fundamental que se criem mecanismos que permitam uma gestão equilibrada do território amenizando os impactos antrópicos no usufruto do meio.

\section{REFERÊNCIAS}

ALBUQUERQUE, A. F. Rede viária e desenvolvimento local: a rodovia PA-151 e a reorganização espacial das comunidades de Bom Jesus e Murutinga, Abaetetuba - Pará. 78f. Monografia (Graduação em Geografia). Universidade Federal do Pará, Abaetetuba (PA), 2003.

ALMEIRA, R. S.; RIBEIRO, M. A. C. "Os sistemas de transporte na Região Norte: evolução e reorganização das redes". In: Revista Brasileira de Geografia, Rio de Janeiro (RJ), v. 51, n. 2, pp. 33-89, abr./jun. 1989.

ANA. Agência Nacional de Águas. Atlas Brasil: abastecimento urbano de água. Brasília: ANA, 2013.

ANA. Agência Nacional de Águas. Atlas Esgoto: despoluição de bacias hidrográficas. Brasília ANA, 2014.

ANDRADE, M. C. Paisagens e problemas do Brasil: aspectos da vida rural brasileira frente à industrialização e ao crescimento econômico. $3^{\text {a }}$ Ed. Rio de Janeiro: Brasiliense, 1970.

ANDRADE, M. C. Geopolítica do Brasil. $2^{\text {a }}$ Ed. São Paulo: Editora Ática,1993.

BORDALO, C. A. L. "O paradoxo das águas: o caso da Amazônia brasileira”. In: Revista GEOUSP (Online), São Paulo (SP), v. 21, n. 1, pp. 120 - 137, jan./abr. 2017.

CARVALHO, J. R. F. Ação e presença dos portugueses na costa norte do Brasil no século XVII: a Guerra do Maranhão 1614-1615. Brasília: Senado Federal, 2014. 
CASTRO, C. J. N. "Belém: da formação da cidade à atuação dos agentes do sistema de transporte urbano". In: SILVA, C. N.; LUZ, L. M.; PONTE, F. C.; RODRIGUES, J. E. C. (Org.). Belém dos 400 anos: análises geográficas e impactos antropogênicos na cidade. Belém: GAPTA/UFPA, 2017, pp.

CAVAlCANTE, M. M. A.; NUNES, D. D.; SIlvA, R. G. C.; LOBATO, L. C. H. "Políticas territoriais e mobilidade populacional na Amazônia: contribuições sobre a área de influência das hidrelétricas no Rio Madeira, Rondônia/Brasil”. In: Confins - Revista Franco-Brasileira de Geografia, São Paulo (SP), v. 1, n. 11, pp. 1-17, 2011.

CÓRDOBA, D.; SELFA, T.; ABRAMS, J. B; SOMBRA, D. "Family farming, agribusiness and the state: Building consent around oil palm expansion in post-neoliberal Brazil”. In: Journal of Rural Studies, Amsterdam, v. 57, pp. 147-156, jan. 2018.

COSTA, W. M. 0 Estado e as políticas territoriais do Brasil. $3^{\text {a }}$ Ed. São Paulo: Contexto, 1991.

CRUZ, E. A história de Belém. Belém: EDUFPA, 1973.

ÉGLER, E. G. “A Zona Bragantina no Estado do Pará”. In: Revista Brasileira de Geografia, Rio de Janeiro (RJ), v. 21 , n. 3, pp. 75-102, 1961.

FASPESPA. Fundação de Amparo a Estudos e Pesquisas do Pará. Estatísticas municipais paraenses: Maracanã. Belém: FAPESPA, 2016.

FURTADO, L. G. "Pesca artesanal: um delineamento de sua história no Pará". In: Boletim do Museu Paraense Emilio Goeldi, Belém (PA), n. 79, p. 1-50, 1981.

FURTADO, L. G. Curralistas e redeiros em Marudá: pescadores do litoral do Pará. Belém: MPEG, 1987.

GONÇALVES, C. W. P. Amazônia, Amazônias. $3^{\text {a }}$ Ed. São Paulo: Contexto, 2012.

GUALBERTO, A. J. P. Embarcações, educação e saberes culturais em um estaleiro naval da Amazônia. 147f. Dissertação (Mestrado em Educação), Universidade do Estado do Pará, Belém (PA), 2009.

LIMA, M. G. M. Mobilidade geográfica como estratégia de sobrevivência de pescadores artesanais na Amazônia: o caso de Cubatão, em Icoaraci, Pará. 120f. Dissertação (Mestrado em Geografia), Universidade Federal do Pará, Belém, 2008.

LOUREIRO, V. R. Os parceiros do mar: natureza e conflito social na pesca da Amazônia. Belém: MPEG, 1985.

LOUREIRO, V. R. Estados, bandidos e heróis: utopia e conflito na Amazônia. Belém: Cejup, 1996.

MACHADO, L. O. "O controle intermitente do território amazônico”. In: Revista Território, Rio de Janeiro (RJ), v. 1, n. 2, pp. 19-33, 1997 .

MIRANDA, R. R. Interfaces do rural e do urbano em área de colonização antiga na Amazônia: estudo de colônias agrícolas em Igarapé-Açu e Castanhal. 213f. Dissertação (Mestrado em Geografia). Universidade Federal do Pará, Belém (PA), 2009.

MOREIRA, R. 0 discurso do avesso: para a crítica da geografia que se ensina. São Paulo: Contexto, 2014.

NAHUM, J. S.; SANTOS, C. B. "Dendeicultura e descampenização na Amazônia paraense”. In: Campo-Território: revista de geografia agrária, Uberlândia (MG), v. 9, n. 17, pp. 469-485, 2014.

OLIVEIRA, A. U. Agricultura camponesa no Brasil. São Paulo: Contexto, 1997.

PENNER, M. E. S. Dialética da atividade pesqueira no Nordeste Amazônico. Belém: EDUFPA, 1984.

PENTEAdo, A. R. Problemas de colonização e uso da terra na Região de Bragantina no Estado do Pará. Belém: EDUFPA, 1967.

PENTEADO, A. R. 0 sistema portuário de Belém. Belém: EDUFPA, 1973.

PRADO JR., C. História econômica do Brasil. 20ª Ed. São Paulo: Brasiliense, 1977. 
REIS, A. C. F. A política de Portugal no vale amazônico. $2^{2}$ Ed. Belém: Secult, 1993.

RIBEIRO, W. O. "Das frágeis conexões às múltiplas interações: estruturação e periodização da rede urbana do nordeste paraense". In: Anais do XI Encontro Nacional da Anpege: a diversidade da geografia brasileira: escalas e dimensões da análise e da ação, Presidente Prudente (SP), outubro de 2015, pp. 5909-5920.

RIBEIRO, W. O. Interações espaciais na rede urbana no Nordeste do Pará: particularidades regionais e diferenças de Bragança, Capanema e Castanhal. 356f. Tese (Doutorado em Geografia). Universidade Estadual Paulista, Presidente Prudente (SP), 2017.

ROCHA, G. M. Todos convergem para o lago!: hidrelétrica de Tucuruí, municípios e territórios na Amazônia. Belém: NUMA/UFPA, 2008.

RODRIGUES, J. C. Produção das desigualdades socioespaciais em cidades médias amazônicas: análise de Santarém e Marabá - Pará. 270f. Tese (Doutorado em Geografia), Universidade Estadual Paulista, Presidente Prudente-SP, 2015.

SANTOS, M. Metamorfoses do espaço habitado: fundamentos teóricos e metodológicos da geografia. $3^{\underline{a}}$ Ed. São Paulo: Hucitec, 1994.

SANTOS, M. 0 espaço dividido: os dois circuitos espaciais da economia urbana nos países subdesenvolvidos. $2^{\mathrm{a}}$ Ed. São Paulo: EDUSP, 2008.

SARGES, M. N. Belém: riquezas produzindo a Belle Époque (1870-1912). 3ª Ed. Belém: Paka-Tatu, 2010.

SOARES, D. A. S. Subsunção do trabalho ao capital na atividade pesqueira paraense: elites locais e contraespaços. $327 \mathrm{f}$. Dissertação (Mestrado em Geografia). Universidade Federal Fluminense, Niterói (RJ), 2016.

SOARES, D. A. S.; LEITE, A. S.; LOBATO, M. M. "Estado e capital: subsídios para a compreensão analítica do protagonismo do Estado brasileiro no rearranjo espacial da América do Sul”. In: Revista Geoamazônia, Belém (PA), v. 4, n. 7, p. $47-77,2016$.

TAGORE, M. P. B. 0 aumento da demanda do açaí e as alterações sociais, ambientais e econômicas: o caso das várzeas de Abaetetuba, Pará. 156f. Dissertação (Mestrado em Gestão dos Recursos Naturais e Desenvolvimento Local na Amazônia), Universidade Federal do Pará, Belém, 2017.

VALVERDE, O.; DIAS, C. V. A rodovia Belém-Brasília: estudo de geografia regional. Rio de Janeiro: IBGE, 1967.

VELHO, O. G. Frentes de expansão e estrutura agrária: estudo do processo de penetração numa área da Transamazônica. $2^{\text {a }}$ Ed. Rio de Janeiro: Zahar, 1972. 